\title{
高減衰積層ゴムの熱・力学的連成挙動の免震建物応答への影響評価 EVALUATION OF THE INFLUENCE OF HEAT-MECHANICS INTERACTION BEHAVIOR IN HIGH-DAMPING RUBBER BEARINGS ON SEISMIC RESPONSE OF BASE-ISOLATED BUILDINGS
}

\author{
北村春幸*1, 早川修平 ${ }^{* 2}$, 竹中康雄 ${ }^{* 3}$, 高岡栄治*4, 室田伸夫*5 \\ Haruyuki KITAMURA, Shuhei HAYAKAWA, Yasuo TAKENAKA, \\ Eiji TAKAOKA and Nobuo MUROTA
}

This paper presents evaluation of the influence on the seismic response of the structures base-isolated with High-Damping Rubber Bearings (HDB) under long-duration, and long-period earthquake motion. The dynamic properties of HDB, such as horizontal stiffness and equivalent damping ratio, are affected by heat in the rubber due to energy absorption during earthquake. In this study, relation of absorbed energy to dynamic properties is investigated by dynamic cyclic-loading test of HDB with large amplitude, and empirical equations are proposed. Additionally, seismic response analysis, under long-period earthquake motion is conducted and the influence of the heat-mechanics interaction of $\mathrm{HDB}$ on the response of the structure is evaluated.

\section{Keywords : Base-isolated structure, High damping rubber bearings, Dynamic loading test, Cyclic deformation, Heat-mechanics interaction behavior, Long period seismic ground motion 免震構造，高減衰積層ゴム，動的載荷試験，繰り返し変形，熱・力学的連成挙動，長周期地震動}

\section{1. はじめに}

近い将来の発生が危惧される東海・東南海・南海地震等の海溝型 巨大地震が起きると東京・横浜，名古屋，大阪などの大都市では， 数秒から十秒の周期の地動が数分から十分間近く続く長周期地震動 に襲われると指摘されている。特に，震源特性やその地域の深い地 下構造に起因した「特定の周期帯」が存在し，その周期帯では応答 スペクトルやエネルギースペクトルが大きなピーク值を示す ${ }^{1)}$

免震建物を支える積層ゴムは，解析モデルに用いる基準值として 1 次・ 2 次水平ばね定数と切片荷重, 鉛直ばね定数など力学特性や, 圧縮・引張限界面圧と限界せん断歪の関係やエネルギー吸収能力な ど限界性能が実大試験により評価されている。さらに，水平ばね定 数と切片荷重は, せん断歪み・面圧・温度に対寸る各種依存性が試 験により評価されている例えば2)。これらの試験により, 減衰性能を併 せ持つ高減衰積層ゴム(HDB)や鉛プラグ入り積層ゴム(LRB)では, 減 衰力を熱エネルギーに変換してエネルギーを消費するため，大きな せん断変形が繰り返し加わると積層ゴムの温度上昇を招き, その結 果として水平剛性や減衰性能が低下寸ることがわかっている ${ }^{3), 4}$ 。本 研究では, この現象を積層ゴムの熱・力学的連成挙動と呼ぶ。

これまで，免震構造の設計の際には，継続時間が数十秒から 120 秒以内の標準波や告示波を用いた時刻歴応答解析から，上部構造の 層間変形角や層せん断力，免震層変位などの最大值に対して耐震性 能を判定してきた。積層ゴムに対してもせん断歪や圧縮・引張面圧 などの最大值に対して耐震性能を判定してきた例えば5)。このような最
大值による評価の前提として，標準波や告示波では，高減衰積層ゴ ム $(\mathrm{HDB})$ や鉛プラグ入り積層ゴム $(\mathrm{LRB})$ の水平ばね定数と切片荷重 の低下が無視できる程度に留まり，かつ限界值がエネルギー吸収量 に対して数倍以上の余裕度を持つことが確認されている例えば4)。免震 構造は免震層の水平変位に応じて 1 次固有周期が 1 秒を下回る值か ら 4,5 秒までの広範囲に変動するため, 長周期地震動の「特定の周 期帯」の影響を受けることになる。さらに，継続時間が標淮波や告 示波の数倍から十倍も長いことも加わって，長周期地震動により免 震構造には，標準波や告示波の数倍からときには十倍以上の地震工 ネルギーが入力することになる ${ }^{1), 6}$ 。従って, 長周期地震動に対して は，一つの地震動による応答解析のなかでも減衰性能を併せ持つ積 層ゴムの減衰性能の低下を考慮することが必要になる。

本研究では，大振幅・多数回繰返しによる積層ゴムの熱・力学的 連成挙動を考慮した免震構造の地震応答解析手法の提案を目的に, 高減衰積層ゴム(HDB) と鉛プラグ入り積層ゴム(LRB)を対象に, 正弦 波及び地震応答波を入力とした大振幅・多数回繰返し変形下での動 的載荷実験を実施した。既報 7)ではこれらの実験データをもとに高 減衰積層ゴムと鉛プラグ入り積層ゴムの多数回繰返し変形下での荷 重変形関係，切片荷重，2 次剛性，ゴム内部温度の変化を示した。 実験結果から，鉛プラグ入り積層ゴムでは吸収エネルギーの増加に 伴い， 2 次剛性の変化は小さいものの，鉛プラグの温度上昇により 切片荷重が 40 60\%に低下し, 高減衰積層ゴムは温度上昇も小さく 力学的特性の変化も小さいことを示した。

\footnotetext{
$* 1$ 東京理科大学理工学部建築学科 教授 $\cdot$ 博士 (工学)

*2 鹿島建設(株) 工修 (元 東京理科大学 大学院生)

*3 鹿島建設株)小堀研究室 室次長·工修

*4 鹿島建設(侏)技術研究所 主任研究員・博士 (工学)

*5 株)ブリヂストン免震開発部 ユニットリーダー・Ph. D.
}

Prof., Dept. of Architecture, Tokyo University of Science, Dr. Eng. Kajima Corporation, M. Eng.

(Former Graduate Student, Tokyo University of Science) Assistant Director, Kobori Research Complex, Kajima Corporation, M. Eng.

Senior Research Engineer, Technical Research Institute, Kajima Corporation, Dr. Eng. Unit Leader, Seismic Isolation Products Dept., Bridgestone Corporation, Ph. D. 
本論文では, 大振幅・多数回繰返し変形下での積層ゴム内部の温 度上昇が累積履歴エネルギー吸収量により置き換えられることを確 認する。実験結果より既往の各種依存式の精度を検討寸るとともに, これまで規定されていなかった履歴依存性の定式化を試みる。次に, これらの各種依存式を適用して, 実験結果から大振幅・多数回繰返 し依存性を抽出し, 高減衰積層ゴムの累積履歴エネルギー吸収量と 水平剛性と減衰性能の関係を定式化する。さらに, 定式化した累積 履歴エネルギー依存式を復元力特性に組込んだ熱・力学的連成挙動 を考慮した免震構造の地震応答解析手法を提案する。最後に, 時刻 歴解析により, 熱・力学的連成挙動による積層ゴムの水平剛性や減 衰性能の低下が, 継続時間が長い長周期地震動による免震構造の応 答性状に与える影響を評価する。

\section{2. 高減衰積層ゴムの基本特性と既往の実験式}

高減衰積層ゴムは，特殊充填剤を配合してゴムの弾性に塑性特性 を付与したもので, ゴム材料そのものが減衰性能を持つ。その結果, 天然ゴム系積層ゴムに比べて, 以下のような依存性が顕在化する ${ }^{4)}$ 。 (1)振幅(歪)依存性 : 小変形では線形で剛性が高く, 大変形ではループ を描き剛性が低下するなど, 振幅に応じて水平剛性が変化する。

(2)振動数(速度)依存性 : 振動数が高くなると水平剛性が大きくなる など, 荷重の載荷速度により水平剛性が変化する。

(3)面圧依存性 : 面圧が高くなると水平剛性が低下し, 座屈限界歪み が減少するなど，面圧により水平剛性が変化する。

(4)温度依存性 : 水平剛性の温度による変化。温度が高くなると水平 剛性が低下する。

(5)履歴依存性 : 大きな水平変形を受けた直後に水平剛性が低下寸る が，時間が経過すると剛性の回復がみられる。

(6)大振幅・多数回繰返し依存性 : 大振幅・多数回繰返しを受けると 減衰エネルギー吸収による温度上昇に伴い水平剛性が低下寸る。 ゴムの塑性が大きいほど，影響を受けやすい。

高減衰積層ゴムの復元力特性は, 図 1 に示すようにスケルトンカ ーブと履歴ループを用いて定式化している。

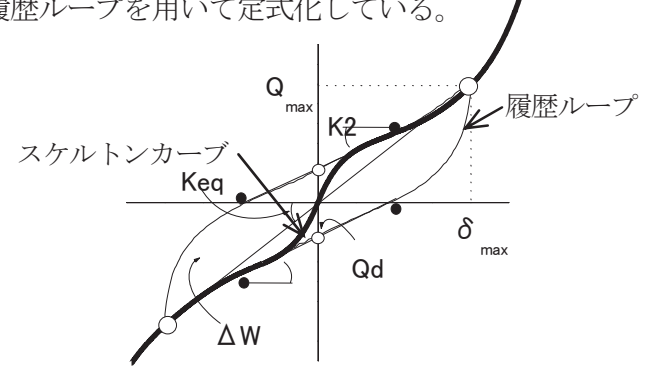

図 1 高減衰積層ゴムの復元力特性の概念図

スケルトンカーブを規定する最大変形 $\delta_{\max }(\gamma)$ と等価せん断剛性 $K_{e q}(\gamma)$ は，ゴム材料により定まる等価せん断弾性率 $G_{e q}(\gamma)$ によって 表される。履歴ループを規定する 2 次剛性 $K_{2}(\gamma)$ と切片荷重 $Q_{d}(\gamma)$ は, $K_{e q}(\gamma)$ と降伏荷重特性係数 $u(\gamma)$ により表され, それまで経験 した最大せん断歪に応じて $K_{2}(\gamma)$ と $Q_{d}(\gamma)$ が変化する履歴則が採用 されている。また, 切片応力 $\tau_{d}(\gamma)$ とせん断弾性率 $G_{2}(\gamma)$ は, $Q_{d}(\gamma)$ と $K_{2}(\gamma)$ により表される。

$$
\begin{aligned}
& \delta_{\max }(\gamma)=h_{r} \cdot \gamma \\
& K_{e q}(\gamma)=G_{e q}(\gamma) \cdot A_{e f} / h_{r} \\
& K_{2}(\gamma)=K_{e q}(\gamma)\{1-u(\gamma)\}
\end{aligned}
$$

$$
\begin{aligned}
& G_{2}(\gamma)=K_{2}(\gamma) \cdot h_{r} / A_{e f} \\
& Q_{d}(\gamma)=u(\gamma) \cdot K_{e q}(\gamma) \cdot h_{r} \cdot \gamma \\
& \tau_{d}(\gamma)=Q_{d}(\gamma) / A_{e f}
\end{aligned}
$$

ここで, $\gamma$ : 積層ゴムのせん断歪 $=\delta / h_{r}$ (ただし, $\left.10 \leq \gamma \leq 270 \%\right)$, $h_{r}$ : ゴム総厚, $A_{e f}$ : 有効断面積 $\left(=\pi / 4 *\left(D^{2}-d^{2}\right)\right), D$ : 内部鋼板外径, $d$ : 内部鋼板内径を示す。この復元力を規定する $G_{e q}, u$ 及び等価減衰定 数 $H_{e q}$ は, せん断歪 $\gamma$ の関数として, 以下のように実験式が与えら れている ${ }^{4)}$

$$
\begin{aligned}
& G_{e q}(\gamma)=G_{e q 0}\left(2.855-3.878 \gamma+2.903 \gamma^{2}-1.016 \gamma^{3}+0.1364 \gamma^{4}\right) \\
& H_{e q}(\gamma)=H_{e q 0}\left(0.9150+0.2364 \gamma-0.1804 \gamma^{2}+0.02902 \gamma^{3}\right)
\end{aligned}
$$$$
u(\gamma)=u_{0}\left(0.9028+0.2711 \gamma-0.2083 \gamma^{2}+0.03421 \gamma^{3}\right)
$$

ここで, $G_{e q 0}, H_{e q 0}, u_{0}: G_{e q}, u, H_{e q}$ の基準值, ゴム材料呼称 X0.6 （材料認定番号:MVBR－0341）の場合は $G_{e q 0}=0.620\left(\mathrm{~N} / \mathrm{mm}^{2}\right)$, $H_{\text {eq }}=0.240, u_{0}=0.408$ で与えられる。なお，基準值は，基準面圧（2 次形状係数 $\mathrm{S}_{2}=3 \sim 10$ に応じて $\sigma_{0}=6 \sim 13 \mathrm{~N} / \mathrm{mm}^{2}$ ), 振幅 $\gamma=100 \%$, 周 期 $3 \mathrm{~s}$ 正弦波加振実験による 3 サイクル目の履歴ループから求めた值 を温度 $20^{\circ} \mathrm{C}$ に換算している。なお，製品検査は，基準面圧，振幅 $\gamma$ $=100 \%$, 周期 $100 \mathrm{~s}$ の基本特性試験による 3 サイクル目の履歴ループ から求めた基本特性值 $G_{e q B}, H_{e q B}, u_{B}$ を用いて検証を行っている。

振動数 $f$ 時の $K_{e q}(f)$ と $H_{e q}(f)$ を規定する振動数(速度)依存性として, 基準振動数 $f_{0}$ 時の $K_{e q}\left(f_{0}\right)$ と $H_{e q}\left(f_{0}\right)$ に乗ずる係数を求める実験式が提 案されている。ゴム材料呼称 X0.6 の場合は, 下式で与えられる。

$$
\begin{aligned}
& K_{e q}(f)=\{0.0628 \log (f)+1.030\} K_{e q}\left(f_{0}\right) \\
& H_{e q}(f)=\{0.0991 \log (f)+1.047\} H_{e q}\left(f_{0}\right)
\end{aligned}
$$

ここに, $f$ : 振動数 $(H z), \quad f_{0}=0.33 H z$

面圧 $\sigma$ 時の $K_{e q}(\sigma)$ と $H_{e q}(\sigma)$ を規定する面圧依存性として, 基準面 圧 $\sigma_{0}$ 時の $K_{e q}\left(\sigma_{0}\right)$ と $H_{e q}\left(\sigma_{0}\right)$ に乗ずる係数を求める実験式が基準と するせん断歪 $\gamma_{0}$ ごとに提案されている。ゴム材料呼称 X0.6 の場合 は，下式で与えられる。

$\gamma_{0}=100 \%$ :

$$
\begin{aligned}
& K_{e q}(\sigma)=\left(1.134-0.003 \sigma-0.001 \sigma^{2}+4.20 \sigma^{3} \times 10^{-5}\right) K_{e q}\left(\sigma_{0}\right) \\
& H_{e q}(\sigma)=\left(0.746+0.009 \sigma+7.926 \sigma^{2} \times 10^{-4}\right) H_{e q}\left(\sigma_{0}\right)
\end{aligned}
$$

$\gamma_{0}=200 \%$ :

$$
\begin{aligned}
& K_{e q}(\sigma)=\left(1.070-0.0075 \sigma-5.10 \sigma^{2} \times 10^{-4}+1.35 \sigma^{3} \times 10^{-5}\right) K_{e q}\left(\sigma_{0}\right) \\
& H_{e q}(\sigma)=\left(0.768+0.008 \sigma+6.679 \sigma^{2} \times 10^{-4}\right) H_{e q}\left(\sigma_{0}\right)
\end{aligned}
$$

ここに, $\sigma:$ 面圧 $\left(\mathrm{N} / \mathrm{mm}^{2}\right), \quad \sigma_{0}=13 \mathrm{~N} / \mathrm{mm}^{2}$

外部温度 $t$ 時の $K_{e q}(t)$ と $H_{e q}(t)$ を規定する温度依存性として, 基準 温度 $t_{0}$ 時の $K_{e q}\left(t_{0}\right)$ と $H_{e q}\left(t_{0}\right)$ に乗ずる係数を求める実験式が提案され ている。ゴム材料呼称 X0.6 の場合は，下式で与えられる。

$$
\begin{aligned}
& K_{e q}(t)=\left\{1.143-1.014 \times 10^{-2} t+2.057 \times 10^{-4} t^{2}-2.943 \times 10^{-6} t^{3}\right\} K_{\text {eq }}\left(t_{0}\right) \\
& H_{e q}(t)=\left\{1.104-5.825 \times 10^{-3} t+1.760 \times 10^{-5} t^{2}+6.396 \times 10^{-7} t^{3}\right\} H_{e q}\left(t_{0}\right) \\
& \text { ここに, } t \text { : ゴム温度 }\left({ }^{\circ} \mathrm{C}\right), \quad t_{0}=20^{\circ} \mathrm{C}
\end{aligned}
$$

高減衰積層ゴムでは，履歷依存性に対応するため製品出荷時に大 振幅 $\gamma=270 \%$ 載荷を行い, 水平剛性を低下させた後, 剛性の回復予 測值を基準值として採用してきた。ゴム材料呼称 X0.6 では，大きな 水平変形を受けた直後の水平剛性の低下が少ないとの判断により, 大振幅載荷を行わずに基準值を定めている。いずれにしろ，時間経 過に応じた水平剛性の変動は考慮されず，設計では一つの基準值が 用いられてきた。

標準波・告示波では一つの地震動のなかでの温度上昇に伴う $K_{e q}$ 
と $H_{e q}$ の変動は小さいと判断され, 大振幅・多数回繰返し依存性は 時刻歴応答解析には考慮されなかった。ただし, 減衰性能を持つ免 震部材について, 終局状態に至るまでのエネルギー吸収量や繰返し 回数依存性などを評価する動的加振実験が行われていた。

\section{3. 動的載荷実験による高減衰積層ゴムの基本特性}

\section{1 実験計画}

高減衰積層ゴムの試験体は，実大装置サイズを直径 $\phi 1000 \mathrm{~mm}$, ゴム総厚 $200 \mathrm{~mm}$ に設定し, 載荷試験機の加振能力を勘案した上で, スケール効果の影響を明らかにするための縮尺を設定し，HDB500 (1/2), HDB300(1/3.3)，HDB225(1/4.4)の縮小試験体を用いた。試験 体一覧を表 1 に示す。縮尺試験体については積層ゴムの熱容量や熱 移動の特性を変化させないよう中間鋼板の厚さなどの積層ゴム各部 の縮尺率が一律になるよう設定している。図 2 に HDB500 試験体の 積層ゴム内部の温度計測位置を示す。温度は熱電対により計測し, ゴム内部 $1 / 2$ 高さ位置に 7 点 $(\mathrm{C} 1 \sim \mathrm{C} 7)$, ゴム内部 $1 / 4$ 高さ位置に 3 点 $(\mathrm{Q} 1 \sim \mathrm{Q} 3)$, 鋼製フランジ下面近傍に 2 点 $(\mathrm{T} 1, \mathrm{~T} 2)$, フランジ上面に 3 点(F1〜F3)の計 15 点とした。

本論文では地震動が始まってから終わるまでの高減衰積層ゴムの 発熱・温度上昇による水平剛性や切片荷重の低下および損傷を確認 するために, 面圧を一定に保った状態で, 積層ゴムに繰返し水平変 形を与える実験と, 地震動終了後, 次の地震動までの水平剛性や切 片荷重の回復の程度を計測する履歴依存性確認実験を行った。 表 2,3,4 に本実験の加振ケース一覧を示す。表 2 の名称 gN1tN2cN3 の数值は, N1 は加振振幅のせん断歪(\%)を, N2 は加振周期(s), N3 は繰返し回数を表す。正弦波加振試験は, 加振周期, せん断歪振幅, 繰返し回数をパラメータに行った。地震波加振は, 表中の地震動に よる, 免震周期 4.0,4.6,5.6 秒, 切片荷重に等価な降伏せん断力係数 0.044,0.03,0.022 の修正 Bi-Linear 型復元力特性を用いた 1 質点系モデ ルによる応答解析を行い, その応答変位波形を用いた ${ }^{7}$ 。履歴依存 性確認実験は，一つの積層ゴムに対して，加振から次の加振までの インターバルとして 2 時間, 4 時間, 18 時間の順に 3 回取る場合と, その逆の順に取る 2 ケースを実施し,さらに 37 日後に加振を行った。 なお，全ての加振ケースの前後に，基本特性值の変化を確認する基 本特性試験を行っている。

\section{2 振動諸元の実験値を基本履歴曲線から求める計算式}

実験で得られる履歴ループから履歴特性を規定する振動諸元 $K_{e q}$, $G_{e q}, H_{e q}, u, Q_{d}$ を求める計算式を以下に示寸。(図 1 参照)

$$
\begin{aligned}
& K_{e q}=\frac{Q_{\max }^{+}+Q_{\max }^{-}}{\delta_{\max }^{+}+\delta_{\max }^{-}} \\
& G_{e q}=K_{e q} \cdot h_{r} / A_{e f} \\
& H_{e q}=\frac{\Delta W}{2 \pi \cdot K_{e q} \cdot \delta_{\max }^{2}} \\
& u=Q_{d} / Q_{\max } \\
& Q_{d}=\frac{Q_{d \max }^{+}+Q_{d \max }^{-}}{2}
\end{aligned}
$$

ここで, $Q_{\text {max }}^{+}, Q_{\text {max }}^{-}$: 正負の最大せん断力, $\delta_{\text {max }}^{+}, \delta_{\text {max }}^{-}$: 正負の 最大変位, $\Delta W: 1$ ループ当たりの履歴エネルギ一吸収量, 基本履 歴曲線において, 歪 $\gamma= \pm 50 \%$ の点を結ぶ直線の傾きを, そのループ における 2 次剛性 $K_{2}$ とする。
表 1 試験体諸元

\begin{tabular}{|l|c|c|c|}
\hline 試験体 & HDB500 & HDB300 & HDB225 \\
\hline 外径 $(\mathrm{mm})$ & 500 & 300 & 225 \\
\hline 内径 $(\mathrm{mm})$ & 15 & 0 & 0 \\
\hline ゴム総厚 $(\mathrm{mm})$ & 102 & 60 & 44.8 \\
\hline 1次形状係数 & 35.7 & 37.5 & 35.2 \\
\hline 2次形状係数 & 4.9 & 5 & 5.02 \\
\hline せん断弾性率 $\left(\mathrm{N} / \mathrm{mm}^{2}\right)$ & 0.62 & 0.62 & 0.62 \\
\hline 等価減衰定数 & 0.24 & 0.24 & 0.24 \\
\hline
\end{tabular}
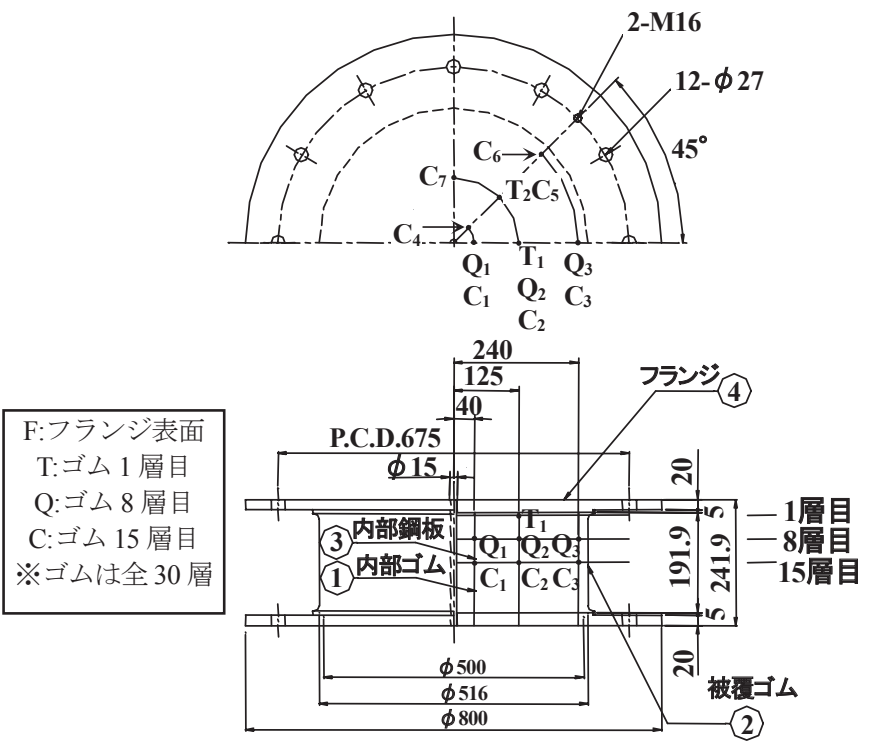

図 2 HDB500 試験体 $の$ 内部温度計測位置

表 2 正弦波加振ケース一覧

\begin{tabular}{|l|c|c|c|c|c|}
\hline \multicolumn{1}{|c|}{ 名称 } & $\begin{array}{c}\text { HDB500 } \\
\text { 加振順 }\end{array}$ & $\begin{array}{c}\text { HDB300 } \\
\text { 加振順 }\end{array}$ & 周期(s) & せん断歪み(\%) & 繰り返し回数 \\
\hline $\mathrm{g} 50 \mathrm{t} 0.75 \mathrm{c} 50$ & 1 & 1 & 0.75 & 50 & 50 \\
\hline $\mathrm{g} 50 \mathrm{t} 3 \mathrm{c} 100$ & 2 & 2 & 3 & 50 & 100 \\
\hline $\mathrm{g} 100 \mathrm{t} 3 \mathrm{c} 100$ & 3 & 3 & 3 & 100 & 50 \\
\hline $\mathrm{g} 100 \mathrm{t} 5 \mathrm{c} 50$ & 4 & 8 & 5 & 100 & 50 \\
\hline $\mathrm{g} 200 \mathrm{t} 5 \mathrm{c} 100$ & 5 & 9 & 5 & 200 & 100 \\
\hline $\mathrm{g} 200 \mathrm{t} 3 \mathrm{c} 100$ & 6 & 4 & 3 & 200 & 100 \\
\hline $\mathrm{g} 100 \mathrm{t} 1.8 \mathrm{c} 100$ & - & 5 & 1.8 & 100 & 100 \\
\hline
\end{tabular}

表 3 地震波加振ケース一覧

\begin{tabular}{|l|c|c|c|c|c|}
\hline $\begin{array}{c}\text { 入力地震波 } \\
\text { 名称 }\end{array}$ & $\begin{array}{c}\text { HDB500 } \\
\text { 加振順 }\end{array}$ & $\begin{array}{c}\text { HDB300 } \\
\text { 加振順 }\end{array}$ & $\begin{array}{c}\text { 最大速度 } \\
\text { (kine) }\end{array}$ & $\begin{array}{c}\text { 主要動継続時間 } \\
\text { Tm(sec) }\end{array}$ & $\begin{array}{c}\text { 最大変形 } \\
\text { Disp(mm) }\end{array}$ \\
\hline JMA KOBE & 7 & - & 45.0 & 180 & 145 \\
\hline JSCA 告示波 & 8 & - & 22.3 & 60 & 118 \\
\hline BCJ L2 & 9 & - & 37.9 & 120 & 218 \\
\hline MEXICO & 10 & - & 41.7 & 180 & 166 \\
\hline TOMAKOMAI & 11 & 6 & 24.8 & 290 & 217 \\
\hline 三の丸 EW & 12 & 7 & 35.1 & 320 & 192 \\
\hline
\end{tabular}

注)HDB300 の加力速度, 変位は HDB500 と相似な值を使用している。

表 4 履歴特性実験加振ケース一覧

\begin{tabular}{|l|c|c|c|c|c|}
\hline 1セット & 面圧 $\left(\mathrm{N} / \mathrm{mm}^{2}\right)$ & 周期(sec) & せん断歪み(\%) & 繰り返し回数 \\
\hline 基本特性(前) & 10 & 100 & 100 & 3 \\
\hline 正弦波 & 5 & 3 & 200 & 50 \\
\hline 基本特性(後) & 10 & 100 & 100 & 3 \\
\hline & 1 回目 & 2 回目 & 3 回目 & 4 回目 & 5 回目 \\
\hline HDB225No.1 & 0 時間 & 2 時間後 & 4 時間後 & 18 時間後 & 37 日後 \\
\hline HDB225No.2 & 0 時間 & 18 時間後 & 4 時間後 & 2 時間後 & 37 日後 \\
\hline
\end{tabular}

\section{3 大振幅 · 多数回繰返し実験による振動諸元の変動}

図 3 に, HDB500 試験体の正弦波加振実験 g100t3c100(せん断歪振 幅 $100 \%$, 加振周期 3s, 繰返し回数 100 回)ケースにおける水平変位 $\delta$ と累積履歴エネルギー吸収量 $E$ の時刻歴, 水平荷重 $Q$ 一水平変位 $\delta$ の関係，試験体各部温度の時刻歴を示す。図 4 亿同じ正弦波加力 実験における，温度または累積履歴エネルギ一吸収量と基準值 $Q_{d 0}$, $K_{2,0}$ に対する切片荷重 $Q_{d}$ 及び 2 次剛性 $K_{2}$ の低下率 $Q_{d} / Q_{d 0}, K_{2} / K_{2,0}$ との関係を時刻歴で示す。

図 3(a),(b)より, 一定振幅での繰返し回数が増えると累積履歴エネ 
ルギー吸収量 $E$ はほぼ線形に増加していき, 最大層せん断力 $Q_{\max }$ は僅かに低下していく。図 3(c)より, 積層ゴムのフランジプレート (F1〜3)の表面温度は上昇が見られず外気温とほぼ同じ值を示す。積 層ゴムの内部温度は，1/2 高さ位置 $(\mathrm{C} 1 \sim \mathrm{C} 7), 1 / 4$ 高さ位置(Q1～Q3) ともに, 表面からの距離が異なってもほぼ同じ值を示す。最初の数 回は大きく温度が上昇するが，その後はほぼ線形に上昇していく。 ゴム表面温度は, 内分温度と外気温度の中間的な值で上昇する。

図 4 より, 切片荷重と 2 次剛性の低下率 $Q_{d} / Q_{d 0}, K_{2} / K_{2,0}$ は, ほぼ同 じ值を示し, 最初の数回は大きく低下し, その後はほぼ同じ割合で 低下していく。高減衰積層ゴムは，せん断変形することにより，内 部ゴムがほぼ一様に温度上昇し, 内部温度に逆比例して切片荷重 $Q_{d}$ と 2 次剛性 $K_{2}$ が低下していく7)。積層ゴム内部での温度分布はほぼ 一様であり, 内部温度と累積履歴エネルギー吸収量は相関関係にあ ると見なせるため, 水平剛性と減衰性能は単位体積当たりの累積履 歴エネルギ一吸収量 $E / V\left(V:\right.$ :゙ム体積 $\left.=A_{e f} \cdot h_{r}\right)$ の関数として評価する。

\section{4 履歴依存性に着目した振動諸元の変動}

図 5 に, HDB500 と HDB300 に対して行った表 2,3 の正弦波加力 実験と基本特性試験の全加力ケースにわたって基準值に対する $G_{e q}$, $u, H_{e q}, G_{2}$ と $\tau_{d}$ の変動を, 積層ゴムの単位体積当たりの累積履歴工 ネルギー吸収量 $E / V$ の累積值を横軸に取って示す。表 4 の履歴特性 確認実験についても同様に，HDB225 に対して行った基本特性試験 を含む全加力ケースについて, 基準值に対する $K_{e q}, u, H_{e q}$ の変動 と $E / V$ の関係を図 6 に示す。図中の $\mathbf{\Delta}$ 印は正弦波加振実験を， $\triangle$ 印 は加振前に， $\triangle$ 印は加振後に行った基本特性試験を示す。

図 5 より, $G_{e q}$ と $G_{2}$ の各加振ケースの 1 サイクル目の值は, 試験

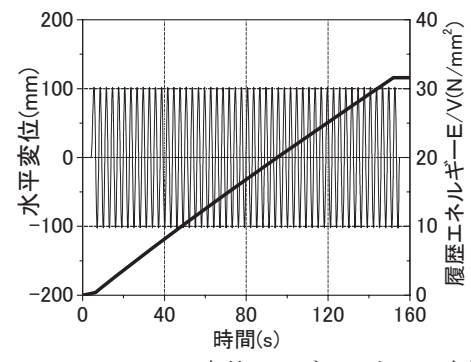

a)変位・エネルギーの時刻歴

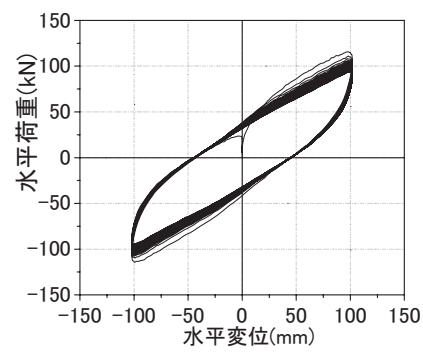

b) 履歴曲線

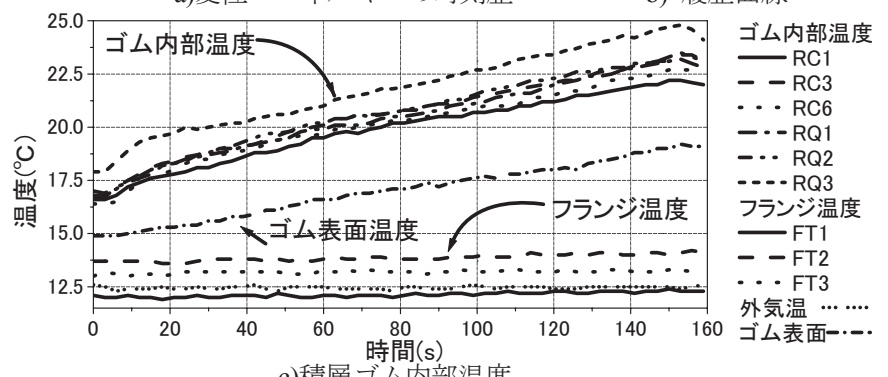

c)積層ゴム内部温度

図 3 正弦波加振実験 (HDB500g100t3c100)
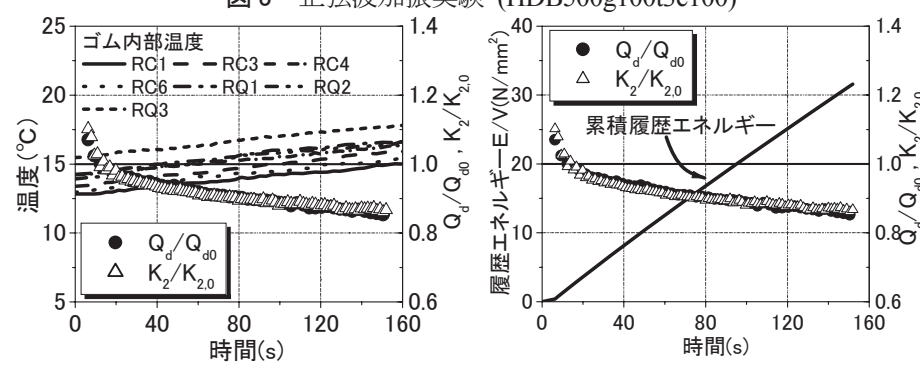

図 4 正弦波加振実験(HDB500 g100t3c100)による力学特性と時刻歴
後のインターバル時間により次の試験では多少回復するが，1 ケー ス目の值が最大で全体的には徐々に低下寸る傾向を示す。どの加振 ケースも，加振が始まる数回は急激に低下し，その後は一定の割合 HDB500

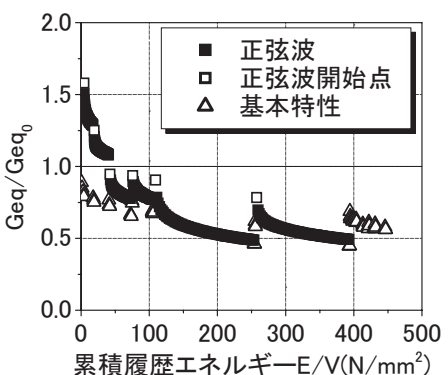
HDB300

a) 等価せん断弾性率 $G_{e q}$
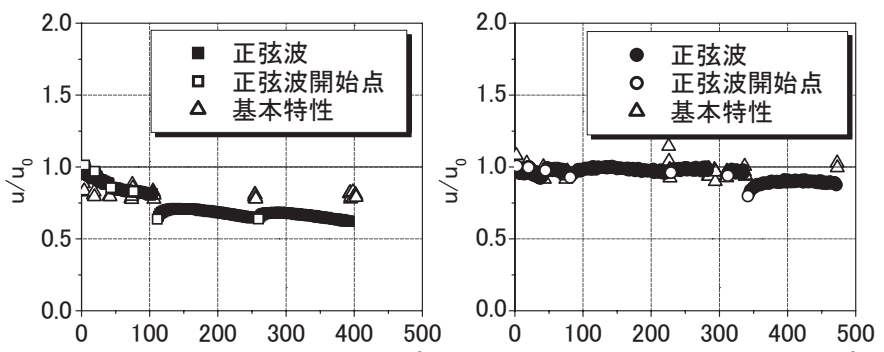

b）降伏荷重特性係数 $u$
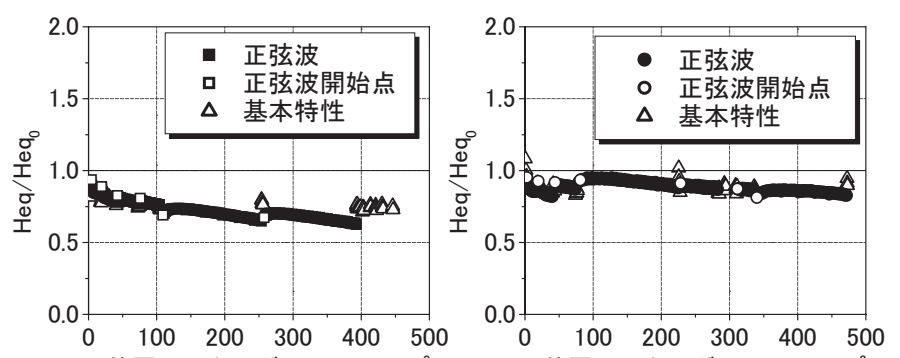

c) 等価減衰定数 $H_{e q}$
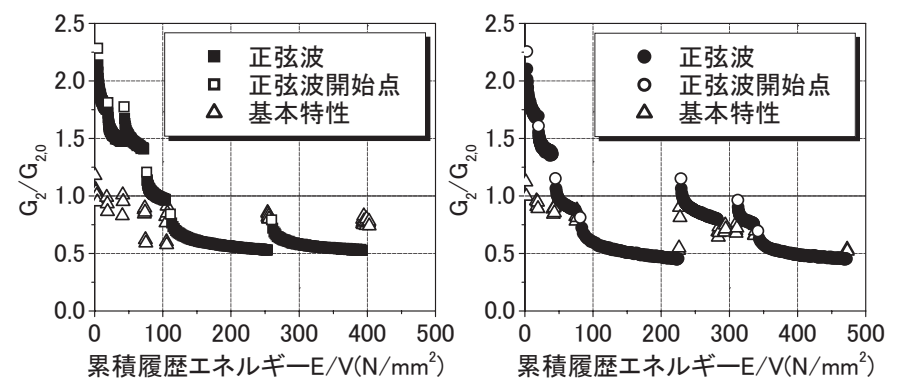

d) せん断弾性率 $G_{2}$
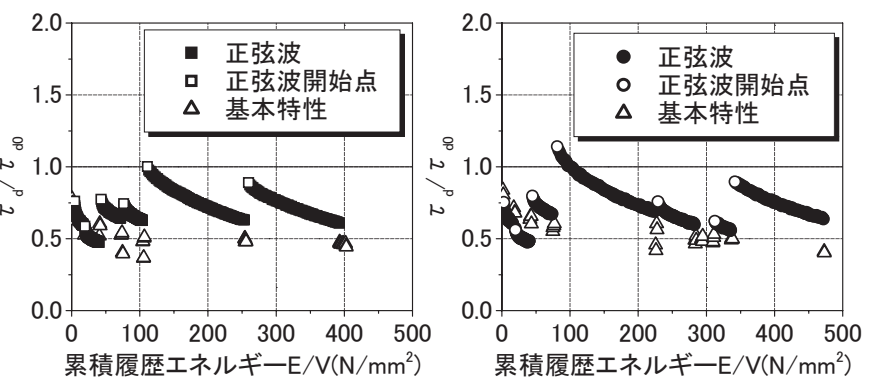

e) 切片応力 $\tau_{\mathrm{d}}$

図 5 基準值に対する $G_{e q}, u, H_{e q}, G_{2}, \tau_{d}$ の変動と $E / V$ の関係 
で低下する傾向を示す。切片応力 $\tau_{d}$ は, どの加振ケースも 1 サイク ル目が最大で加振回数が増えると低下していく。加振実験の前後に 行われる基本特性試験における切片応力 $\tau_{d}$ は, 累積履歴エネルギー 吸収量が増加することにより僅かに低下する傾向を示すがその影響 は小さい。また, 降伏荷重特性係数 $u$ と等価減衰定数 $H_{e q}$ は 1 ケー ス目の 1 サイクル目が最大で, 徐々に低下寸る傾向を示すがその影 響は小さい。低下率が小さいため, インターバル時間による回復も 無視できる程度に留まる。

図 6 より, いずれの加振ケースにおいても, 加振中の等価せん断 弾性率 $G_{e q}$ は, ほぼ同じ割合で低下寸る。加振後の基本特性試験に おける等価せん断弾性率 $G_{\text {eq }}$ はほぼ同じ值を示し, 加振前の基本特 性試験における $G_{e q}$ はインターバル時間が長くなるほど初期值に近 づき, 回復の割合が増す。降伏荷重特性係数 $u$ と等価減衰定数 $H_{e q}$ は, 加振回数が増えても僅かに低下寸るのみで, 累積履歴エネルギ 一吸収量の影響は小さい。従って, インターバルによる回復も無視 できる。積層ゴムの復元力特性は, $G_{e q}, u, H_{e q}$ により規定される。 図 6(b),(c)から正弦波加振時の $u / u_{0}$ 及び $H_{e q} / H_{e q 0}$ と $E / V$ の関係を直線 で近似する。それら勾配の平均值はそれぞれ- $0.0002,-0.0004$ で あり, 正弦波加振による $E / V$ が概ね $100 \mathrm{~N} / \mathrm{mm}^{2}$ であることから加振

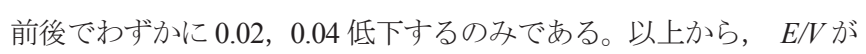
$u$ と $H_{e q}$ に与える影響は小さいと判断して, $u / u_{0}=1.0, H_{e q} / H_{e q 0}=1.0$ と設定する。以降は， $G_{e q}$ と $E / V$ との関係の定式化を試みる。

\section{5 基本特性試験に基づく履歴依存性の定式化}

ここでは, 表 2,4 の正弦波加振実験の前後に行われる基本特性試 験の結果をもとに，等価せん断剛性 $K_{e q}$ の回復率とインターバル時 間 $t$ との関係の定式化を試みる。図 7 に積層ゴムの単位体積当たり の累積履歴エネルギー吸収量 $E / V$ を横軸に取り, 加振実験の前後に 行われた基本特性試験の等価せん断剛性 $K_{e q B}$ の, 最初に実施した基 本特性試験の值 $K_{e q B 1}$ に対する比率 $K_{e q B} / K_{e q B 1}$ を示す。

図 7 より, 積層ゴムの累積塑性エネルギーが大きくなるほど等価 せん断岡性の低下率 $K_{e q B} / K_{e q B 1}$ は大きくなるが, 積層ゴムの大きさ $500 \phi, 300 \phi, 225 \phi$ に関係なく, 破線で示寸下限に収斂している。 ここでは, 実験における最大振幅 $\gamma= \pm 200 \%$ 時の值を, 下限值 $K_{e q B} / K_{e q B 1}=0.6$ として採用する。

図 8(a)に $i$-1 番目の加振実験の直後に行った基本特性試験の $K_{e q B a, i-1}$ 值と次の $i$ 番目の加振実験の直前に行った基本特性試験の $K_{e q B b, i}$ 值 との比率 $K_{e q B b, i} / K_{e q B a, i-1}$ と $i-1$ 番目と $i$ 番目の加振実験のインターバル 時間 $t$ との関係を示す。図 7 から求めた下限值 $K_{e q B} / K_{e q B 1}=0.6$ を, 図 $8(\mathrm{a})$ の $K_{e q B b, i} / K_{e q B a, i-1}$ に乗じた值を回復率 $K_{e q R}$ と定義し, 下式で表す。

$$
K_{e q R}=\frac{K_{e q B}}{K_{e q B 1}} \cdot \frac{K_{e q B b, i}}{K_{e q B a, i-1}}=0.6 \frac{K_{e q B b, i}}{K_{e q B a, i-1}}
$$

等価せん断岡性の回復率 $K_{e q R}$ とインターバル時間 $t$ との関係を図 8(b)に示す。(5)履歴依存性として, 図 8(b)より回復率 $K_{\text {eqR }}$ をインタ 一バル時間 $t$ の関数で表す。 $t=0$ のとき 0.6 に $t=\infty$ のき 1.0 とな ることから, 回復率 $K_{e q R}(t)$ として下式を設定する。

$$
K_{e q R}(t)=1.0-\frac{0.4}{1+0.1 t^{0.5}}
$$

なお, 等価減衰定数の回復率 $H_{e q R}(t)$ は, 図 6(b)よりインターバルに よる回復も無視できることから，下式を設定する。

$$
H_{e q R}(t)=1.0
$$
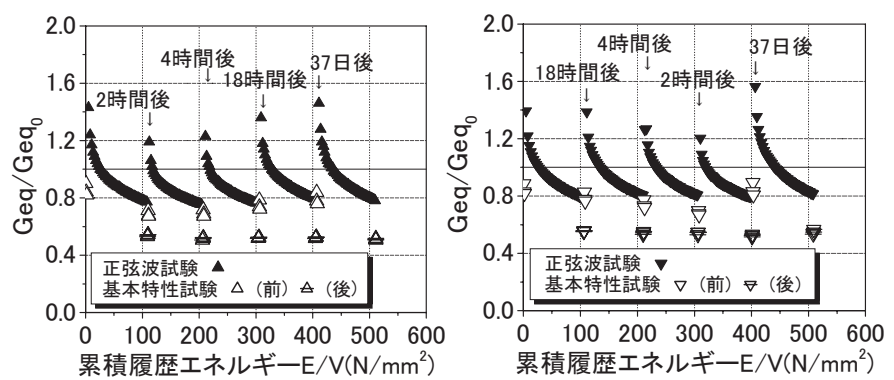

(a) 等価せん断弾性率 $G_{e q}$
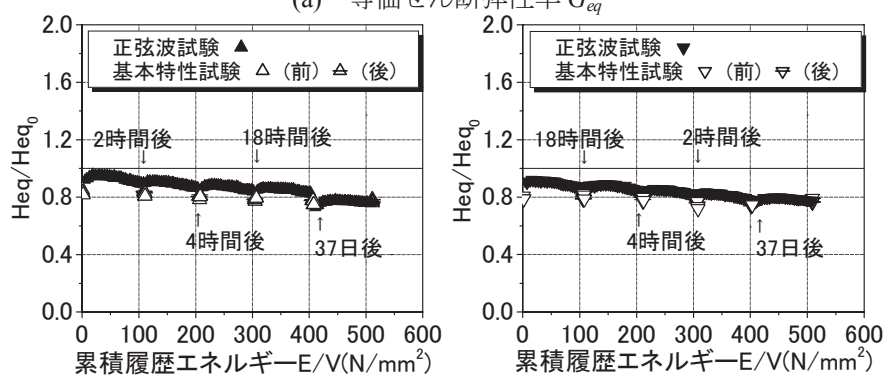

(b) 等価減衰定数 $H_{e q}$
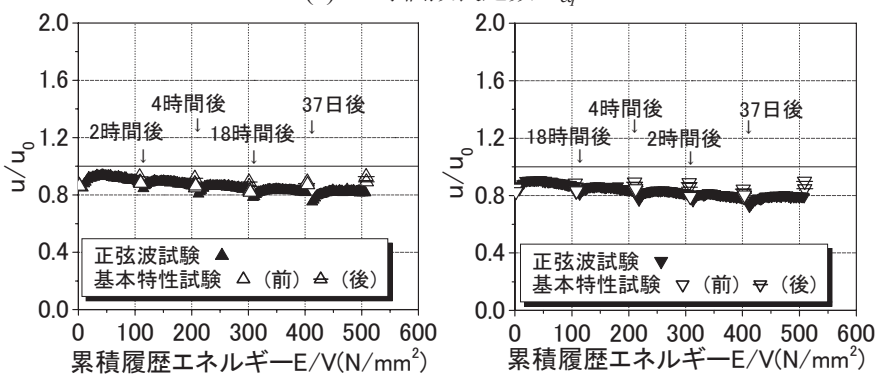

（c）降伏荷重特性係数 $u$

図 6 基準値に対する $K_{e q}, H_{e q}, u$ の変動と $E / V$ の関係

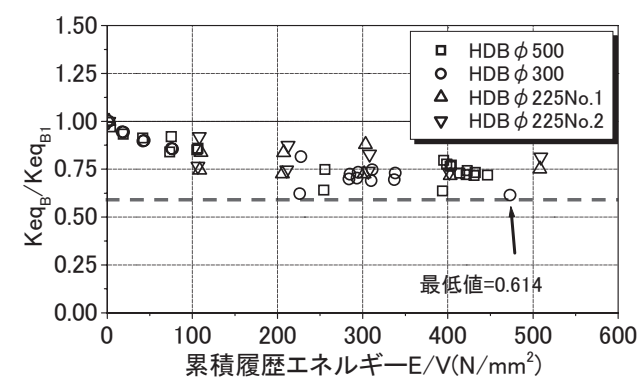

図 7 等価せん断剛性 $K_{e q B} / K_{e q B 1}$ と累積履歴エネルギーの関係

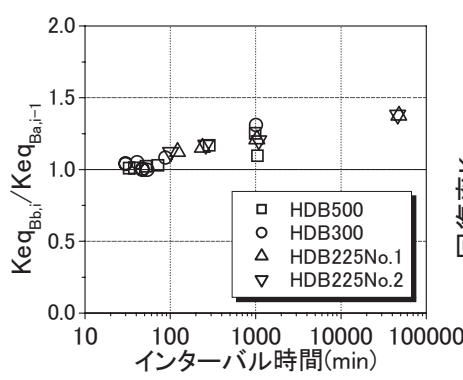

(a) $K_{\text {eqbi,i }} / K_{\text {eqa }, i-1}$

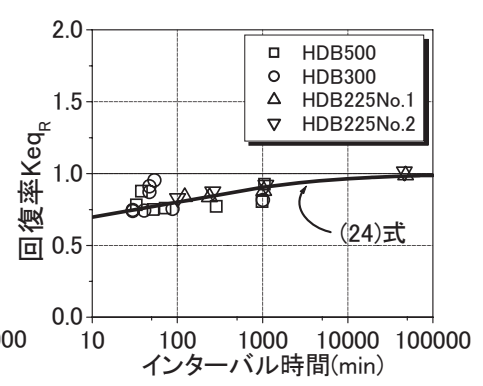

(b) 回復率 $K_{\text {eqR }}$
図 8 等価せん断剛性の回復率とインターバル時間の関係

\section{4. 各種依存式の加振実験に基づく検証}

\section{1 振幅 (歪) 依存式の検証}

図 5(a),(d)より， $\gamma=200 \%$ の大歪振幅で繰返し回数 100 回の正弦波 加振を受けた後は, 本実験のインターバル時間では力学特性の十分 な回復が望めない。従って, 振幅依存式の検証は, 表 2 に示寸歪振 
幅 $\gamma=50,100,200 \%$ で加振順序が HDB500 で 6 ケースまで, HDB300 で 4 ケースまでの比較的累積履歴エネルギー吸収量の少ない範囲の 正弦波加振実験の結果に対して行う。それらの3 サイクル目の履歴 ループから求めた $G_{e q}, H_{e q}$ と加振歪振幅 $\gamma$ の関係を図 9 に示す。左 列の図は実験值を, 右列は実験值に歪振幅以外の振動数(10),(11)式, 面圧(12) (15)式, 温度(16),(17)式, インターバル時間(24),(25)式によ る補正を加えた值 $G_{e q}^{\prime}, H_{e q}^{\prime}$ (符号に'を付加)を示す。インターバル 時間 $t$ は直前の正弦波または地震波による加振実験終了時からの経 過時間とする。図中の太実線は, $G_{e q}(\gamma)$ と $H_{e q}(\gamma)$ の歪振幅依存式 (7),(8)を示す。図 9 より, 等価せん断弾性率 $G_{e q}$ は歪振幅が大きくな るに従って急激に低下寸るが, 等価減衰定数 $H_{e q}$ は歪振幅に依存せ ず概ね一定の值を示す。また， $G_{e q}, H_{e q}$ ともに，積層ゴム $300 \phi$ と $500 \phi$ の差は少ない。歪振幅依存式は実験值の傾向を比較的良く捉え ており, 補正後の值に対してはほぼ平均的な值を示す。しかしなが ら，補正值は依存式に対して 2,3 割の幅を持ってばらつく。

\section{2 振動数 (速度) 依存式の検証}

振動数依存式(10),(11)は, 平 12 建告第 1446 号免震材料認定 ${ }^{5)}$ にお ける基淮值(加振振動数 $0.33 \mathrm{~Hz}$ ) と出荷時の製品検査で行われる基本 特性值(加振振動数 $0.01 \mathrm{~Hz}$ ) とを関係付けるために作られた振動数補 正式であり, 振動数 $f=0.01,0.02,0.05,0.1,0.2,0.33 \mathrm{~Hz}$ の 6 点の実験結 果を用いて作成されている。図 9 と同じ正弦波加振実験の結果を用 いて, 等価せん断岡性と等価減衰定数の基準值 $K_{e q 0}, H_{e q 0}$ に対寸る実 験值 $K_{e q}, H_{e q}$ の比率 $K_{e q} / K_{e q 0}, H_{e q} / H_{e q 0}$ と加振振動数 $f(\mathrm{~Hz})$ の関係を図 10 に示寸。左列の図は実験值を, 右列は実験值に振動数以外の歪振 幅(2),(7),(8)式，面圧(12)〜(15)式，温度(16),(17)式，インターバル時 間(24),(25)式による補正を加えた值 $K_{e q 0}^{\prime} / K_{e q 0}, H_{e q 0}^{\prime} / H_{e q 0}$ を示す。眓中 の太実線は, 振動数 $f=0.01 \sim 0.33 \mathrm{~Hz}$ の範囲で求めた $G_{e q}(f)$ と $H_{e q}(f)$ の 振動数依存式 (10),(11)を表し, それらを $0.001 \sim 5 \mathrm{~Hz}$ まで外挿して太 破線で示す。図 10 より, $G_{e q}, H_{e q}$ ともに振動数に比例して僅かに大 きくなる傾向を示す。また, 振動数依存式は補正後の值に対してほ ぼ平均的な值を示すが, 補正後の值は 2,3 割の幅でばらつく。

\section{3 各種依存式の検証}

積層ゴムの累積履歴エネルギー吸収量 $E / V$ を横軸に取って, 表 2 に示寸正弦波加振試験と基本特性試験の全てについて，それぞれの 3 サイクル目の履歴ループから求めた等価せん断剛性と等価減衰定 数の基準值に対する比率 $K_{e q} / K_{e q 0}, H_{e q} / H_{e q 0}$ を図 11 示す。左列の図は 実験值を, 右列は実験值に各種依存性式(2),(7)〜(17),(24),(25)を用い た補正を加えた值 $K^{\prime}{ }^{\prime}{ }^{\prime} 0 / K_{e q 0}, H^{\prime}{ }^{\prime} 0 / H_{e q 0}$ を示す。図中, $\square$ と○がそれ ぞれ HDB500 と HDB300 の図 9,10 に示した累積履歴エネルギー吸 収量の少ない範囲の正弦波加振実験の值を,

弦波加振実験と基本特性試験の值を示す。

図 11 の左列の実験值 $K_{e q} / K_{e q 0}, H_{e q} / H_{e q 0}$ は，1 日の実験終了後, 翌 日の実験まで若干の回復が見られるものの, 全体的に右下がりの傾 向を示寸。右列の補正後の值 $K_{e q 0}^{\prime} / K_{e q 0}, H_{e q}^{\prime} 0 / H_{e q 0}$ は, 大幅に改善さ れ，ともに 1.0 の近傍にばらつき, 補正が有効なことを示している。 ただし， $K_{e q 0}^{\prime} / K_{e q 0}$ については累積履歴エネルギー吸収量の多いロ

○印は徐々に低下し，へたる傾向を示す。

以上の検討から，振幅(2),(7),(8)式，振動数(10),(11)式，面圧(12) (15)式，温度(16),(17)式，インターバル時間(24),(25)式を用いた補正 は実験值の概ね平均的な值を示し，妥当であることがわかる。ただ
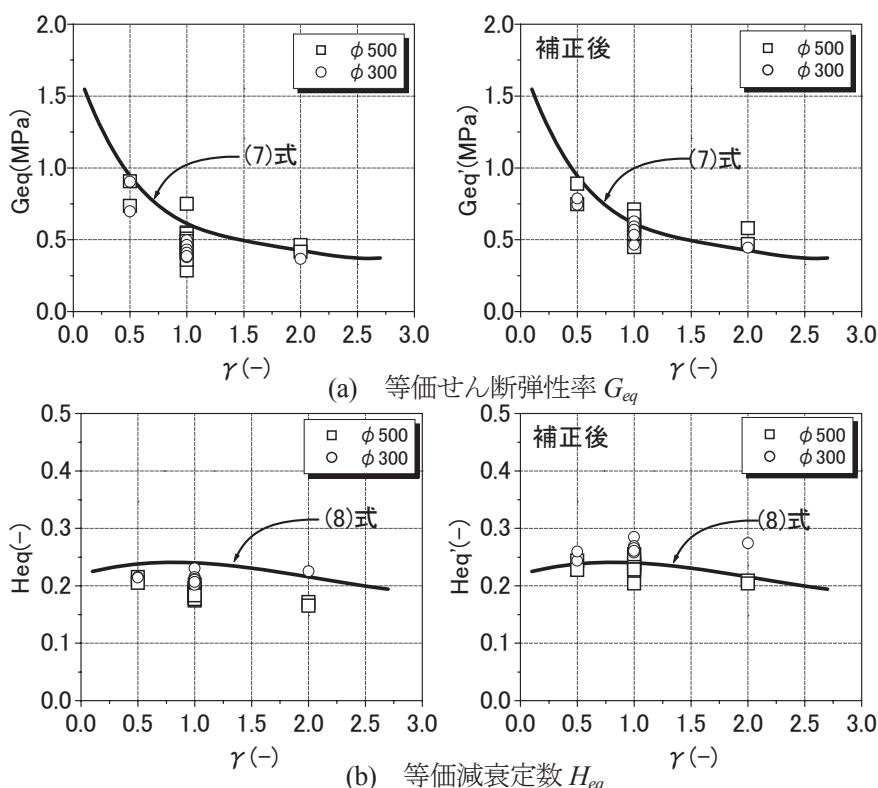

図 9 振幅依存性に関する実験值と実験式の比較
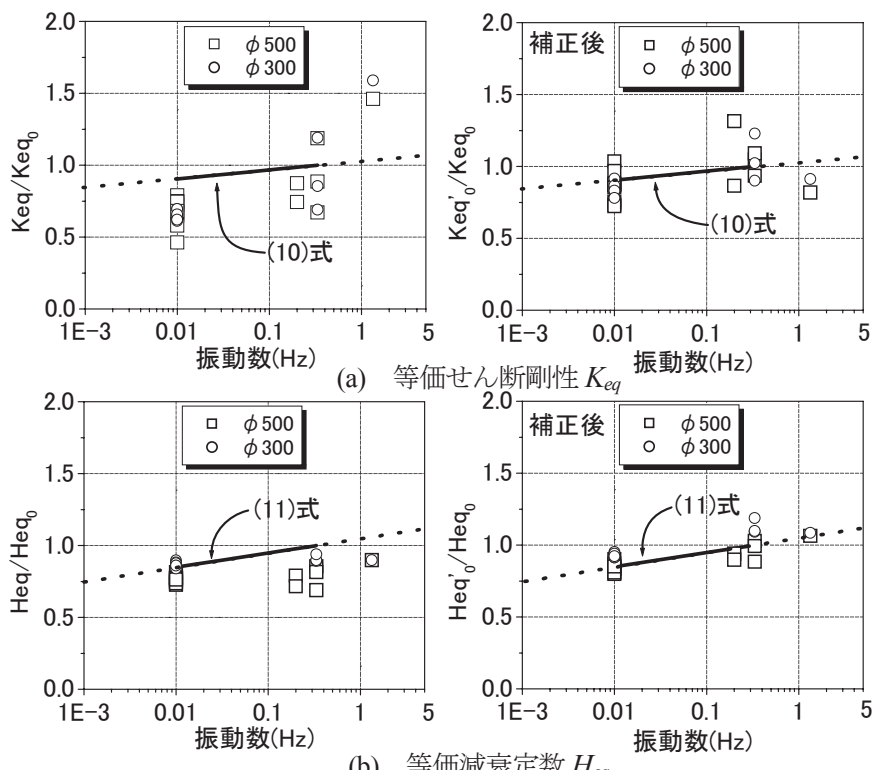

図 10 振動数依存性に関する実験值と実験式の比較
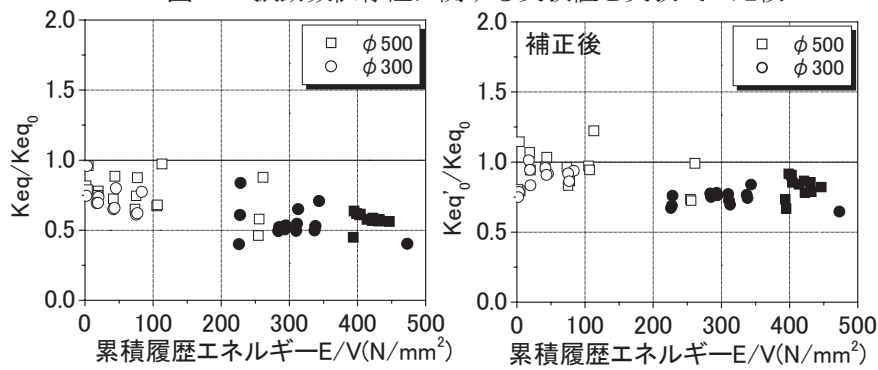

(a) 等価せん断剛性 $K_{e q}$

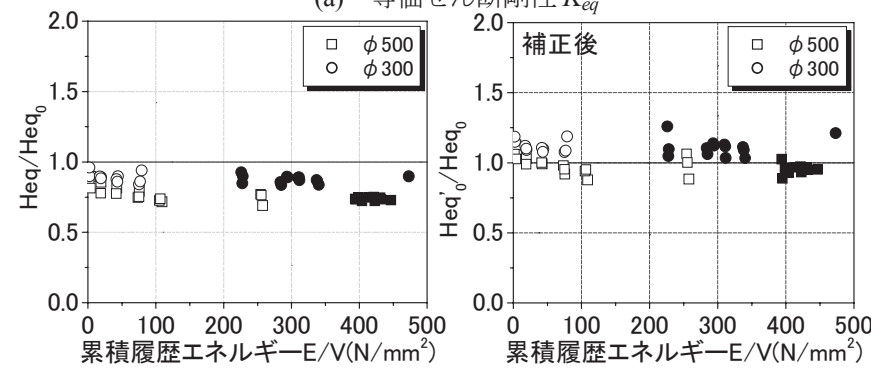

(b) 等価減衰定数 $H_{e q}$

図 11 正弦波加振実験を用いた各種依存式の検証 
し，実験值は 2,3 割の幅でばらつく。

5. 大振幅 - 多数回繰返し実験による熱 - 力学的連成挙動の定式化 表 2 に示寸繰返し回数 50,100 回の正弦波加振実験の結果を用いて, 積層ゴムの等価せん断岡性 $K_{e q}$ と累積履歴エネルギー吸収量 $E / V$ と の関係の定式化を試みる。図 12 に各種依存式(2),(7)〜(17),(24),(25) による補正を加えた等価せん断岡性 $K^{\prime}{ }_{e q 0}$ の基準值 $K_{e q 0}$ に対する比率 $K_{e q 0}^{\prime} / K_{e q 0}$ と累積履歴エネルギー $E / V$ の関係を示す。補正式そのもの が実験值に対してばらつきを示すため, 図 12 の $K_{e q 0}^{\prime} / K_{e q 0}$ と $E / V$ の 関係にもばらつきが現れる。ただし， $K_{e q 0}^{\prime} / K_{e q 0}$ と $E / V$ の関係は, 積 層ゴムの直径, 加振振幅や振動数が異なっても, 最初は急激に低下 するがその後は緩やかに減少する相似な性状を示す。そこで, 各種 依存性式が 3 サイクル目の履歴ループから求まる值を定めているこ とに着目して，3 サイクル目の履歴ループから求めた等価せん断剛 性 $K_{e q 3}$ を基準にした等価せん断岡性の低下率 $K_{e q} / K_{e q 3}$ と $E / V$ の関係 を図 13 に示寸。図中の横軸の $E / V$ は, 3 サイクル目を原点として 1 から 2 サイクル目は負の值で示す。免震層の剛性の低下を大きく見 込むことは応答変位にとって安全側の評価になることから, 図 13 において下限值を包絡するよう, $K_{e q} / K_{e q 3}$ と $\left(E-E_{3}\right) / V$ の関係を下式で 定める。

$$
\frac{K_{e q}}{K_{e q 3}}\left(\frac{E-E_{3}}{V}\right)=-2.5+0.1 e^{-\left(\frac{E-E_{3}}{3 V}\right)}+3.4 e^{-\left(\frac{E-E_{3}}{1000 V}\right)}
$$

(26)式中の 3 サイクル目までの $E_{3} / V$ は，振幅，振動数により異な るが，ここでは基準值 $K_{e q 0}$ を定める基準面圧，加振振幅 $\gamma=100 \%$, 加振周期 $3 \mathrm{~s}$ の正弦波加振実験による 3 サイクル目までの值を用いる ことにする。求めた $E_{3} / V=2.1 \mathrm{~N} / \mathrm{mm}^{2}$ を(27)式に代入して, 1 サイク ル目からの $K_{e q} / K_{e q 0}$ と $E / V$ の関係式を下式で定める。

$$
\frac{K_{e q}}{K_{e q 0}}\left(\frac{E}{V}\right)=-2.5+0.2 e^{-(E / V)}+3.4 e^{-(E / 1000 V)}
$$

表 3 に示す地震波加振実験の結果を用いて, 累積履歴エネルギー 依存式(27)を検証する。HDB500 加振実験の中から苫小牧波と三の 丸 EW 波の履歴ループを図 14(a)に示す。図 14(a)中の $\square$ 印で示寸履 歴曲線の正負のピーク值から $K_{e q}$ を求め, この值に振幅(2),(7),(8)式, 振動数(10),(11)式, 面圧(12) (15)式, 温度(16),(17)式による補正を加 えた值 $K_{e q 0}^{\prime}$ を求める。等価せん断剛性の低下率 $K_{e q H}$ は, $K_{e q 0}^{\prime} 0 K_{e q 0}$ に履歴依存性を考慮するため, 最初の基本特性試験の值 $K_{e q B 1}$ と地震 波加振実験の直前に行われた基本特性試験の值 $K_{e q B i}$ の比率 $K_{e q B 1} / K_{e q B i}$ を乗じた下式で定める。

$$
K_{e q H}=\frac{K_{e q B 1}}{K_{e q B i}} \cdot \frac{K_{e q 0}}{K_{e q 0}}
$$

等価せん断岡性の低下率 $K_{\text {eqH }}$ と累積履歴エネルギー吸収量 $E / V$ の 関係を図 14(b)に示す。図中の $\square$ 印は図 14(a)中の $\square$ 印で示寸履歴曲 線の正負のピーク值から求まる $K_{e q H}$ を示し, 実線は(27)式を示す。 図 14(b)より, 実験值にばらつきが見られるものの, (27)式は地震波 加振実験から求まる值のほぼ平均的な值を示すことがわかる。

\section{6. 積層ゴムの熱・ 力学的連成挙動を考慮した地震応答解析法}

これまで，高減衰積層ゴムの復元力特性は，歪依存性を考慮した 修正 Bi-linear 型が一般的に用いられてきた。この復元力特性の中の 等価剛性 $K_{e q}(\gamma)$ 歪依存式(7)に累積履歴エネルギー依存式(27)を付

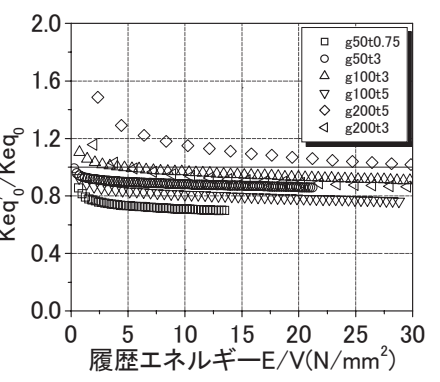

(a) HDB500

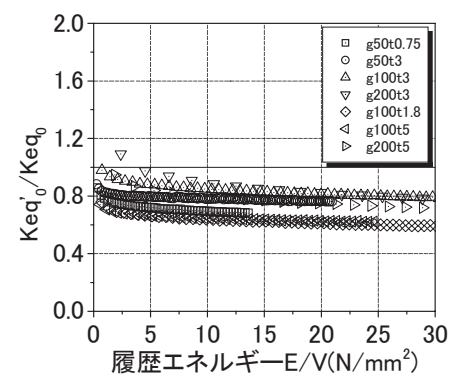

(b) HDB300
図 12 大振幅・多数回繰返し実験における $K^{\prime}{ }^{\prime} 0 / K_{e q 0}$ と $E / V$ の関係

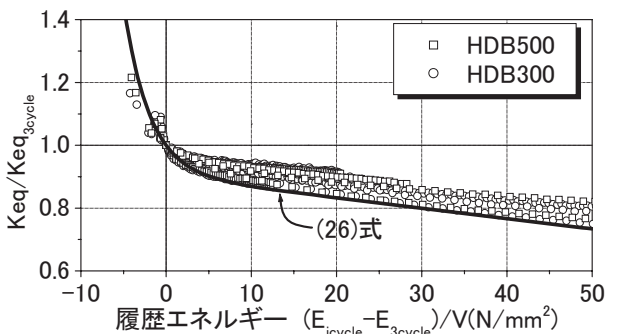

図 133 サイクル目で規準化じを た $K_{e q} \mid K_{\text {eq } 3}$ と $E / V$ の関係
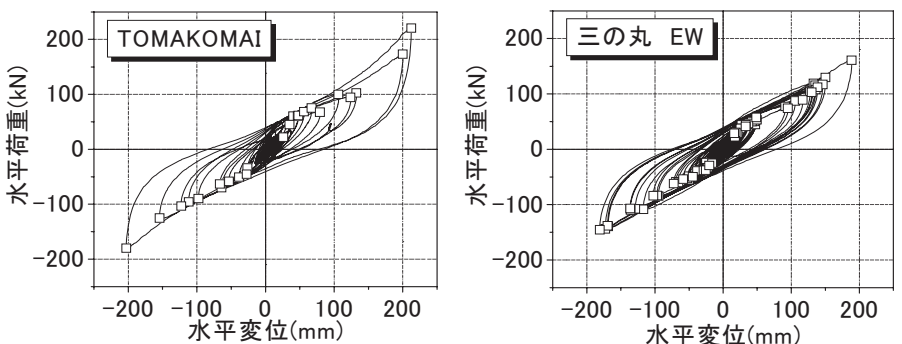

(a) 履歴ループ
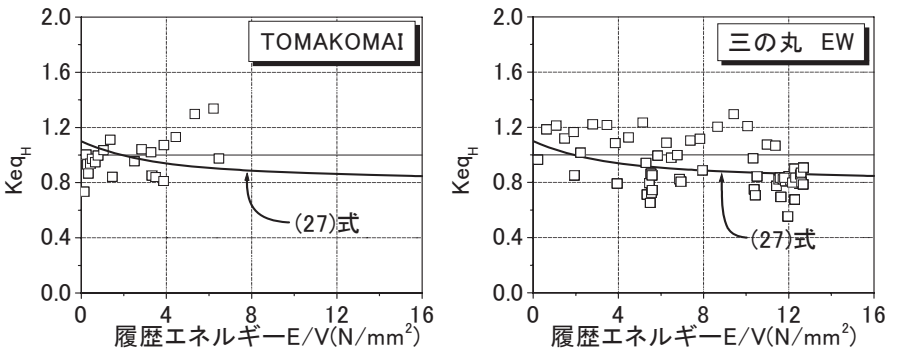

(b) $K_{e q} / K_{e q 0}$ と $E_{3} / V$

図 14 地震動加振実験の $K_{e q} / K_{e q 0}-E_{3} / V$ 関係を用いた実験式の検証
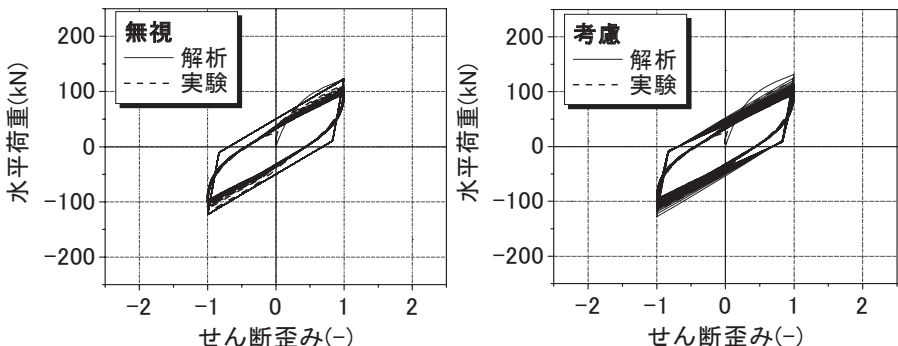

(a) 正弦波加振実験 HDB500g100t3.0c50
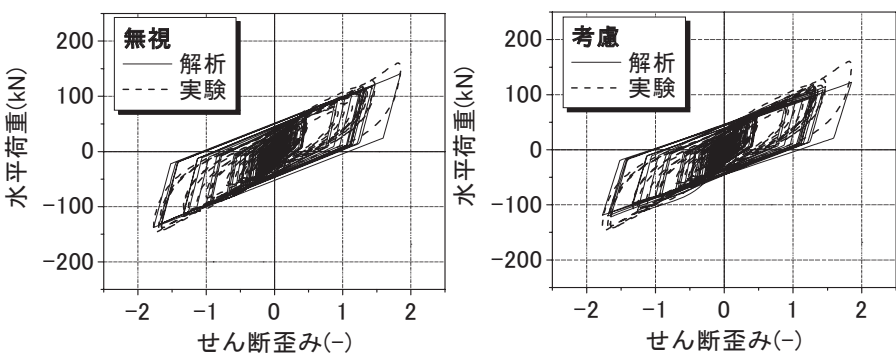

(b) 地震波加振実験 HDB500 三の丸波

図 15 加振実験の履歴曲線を用いた熱・力学的連成挙動の影響評価 
け加え, 熱・力学的挙動を考慮した復元力特性を下式で設定する。

$$
K_{e q}(\gamma, E / V)=G_{e q 0} \cdot A_{e f} / h_{r}\left(-2.5+0.2 e^{-(E / V)}+3.4 e^{-(E / 1000 V)}\right) \text {. }
$$$$
\left(2.855-3.878 \gamma+2.903 \gamma^{2}-1.016 \gamma^{3}+0.1364 \gamma^{4}\right)
$$

表 2 の正弦波加振実験 HDB500g100t3.0c50 と, 表 3 の地震波加振 実験 HDB500 三の丸波について, (7)式を用いた累積履歴エネルギー 依存性を無視した場合と(29)式を用いた累積履歴エネルギー依存性 を考慮した場合の解析值と実験值の履歴曲線と累積履歴エネルギー の時刻歴による比較をそれぞれ図 15，16 に示す。図 15(a),(b)より， 地震波加振実験におけるせん断歪 $150 \%$ 以上に現れるハードニング を除き, 累積履歴エネルギー依存性を考慮した解析結果は, 実験結 果に現れる切片荷重 $Q_{d}, 2$ 次剛性 $K_{2}$, 最大せん断力 $Q_{\max }$ の低下を よく表している。また, 図 16 より, 累積履歴エネルギ一依存性を無 視した場合, 実験值に比べて累積履歴エネルギー吸収量が 1.5 倍程 度多かったものが，考慮することにより 1.2 倍程度まで近づいてい る。 $K_{e q 0}^{\prime} / K_{e q 0}$ の下限值を取ることで岡性低下を多めに評価してきた が，エネルギー吸収量の低下に対しては不十分なようである。これ は $G_{e q}, u, H_{e q}$ の振幅(歪)依存式(7),(8),(9)のばらつきと, $H_{e q}$ の累積 履歴エネルギー依存式を $H_{e q} / H_{e q 0}=1.0$ としたことによる誤差に起因 すると思われる。以上の検討から, 修正 Bi-linear 型の高減衰積層ゴ ムの復元力特性そのものも, さらにその復元力特性に累積履歴エネ ルギー依存式を付与した(29)式も, 加振実験による累積履歴エネル ギー依存性を概ね考慮するものと判断できるが，応答結果の評価の 際には 2,3 割のばらつきを含むことを前提にする必要がある。従っ て, 7 章の免震建物の応答性状の検討にあたっては, 累積履歴エネ ルギー依存性を考慮した場合と無視した場合の比較を主な検討とす る。

\section{7. 積層ゴムの熱・ 力学的連成挙動を考慮した免震建物の応答性状}

\section{1 解析モデルの作成手順}

熱・力学的連成挙動を考慮することによる応答に与える影響を検 討するための解析モデルの作成手順を以下に示す。

(1)高減衰積層ゴムを使用した免震建物を質点系にモデル化する。

(2)各種依存性を考慮するために, 基準值 $K_{e q}, H_{e q}$ に乗ずる係数を求 める。振動数(速度)依存性は免震建物の応答せん断歪を想定した 等価周期を(10),(11)式に代入して, 面圧依存性は常時面圧を(12) （15)式に代入して，温度依存性は想定外気温度を(16),(17)式に 代入して, 履歴依存性は免震層に変位を与えた地震から経過時間 を(24)式に代入して，それぞれの係数を求める。

(3)(2)の係数を考慮した上で免震層の復元力特性は, 振幅(歪)依存性 と累積履歴エネルギー依存性を考慮した(29)式を用いた場合と 振幅(歪)依存性の夕を考慮し累積履歴エネルギ一依存性を無視 した(2)式を用いた場合について，地震応答解析を行う。

\section{2 解析モデルと検討用入力地震動}

直径 $\phi 800, \phi 1000, \phi 1200$ の高減衰積層ゴムとその常時面圧を 8 $\sim 13 \mathrm{~N} / \mathrm{mm}^{2}$ に設定し, (7)式を用いたせん断ひずみ $\gamma=1.0$ 時の等価免 震周期 $T_{e q}=3.0 \sim 4.5 \mathrm{~s}$ となる 1 質点系モデルを作成する。解析モデル の諸元を表 5 に示す。表中の $C_{d}$ はせん断ひずみ $\gamma=2.0$ のときの(2) 式を用いた復元力特性の切片荷重の建物重量に対する比率を示す。 作成手順(2)で求めた基準值に乗ずる係数は，4 つの解析モデルの $K_{e q}$ で $0.97 \sim 1.0, H_{e q}$ で 1.0 1.14 であり，ここでは累積履歴エネル
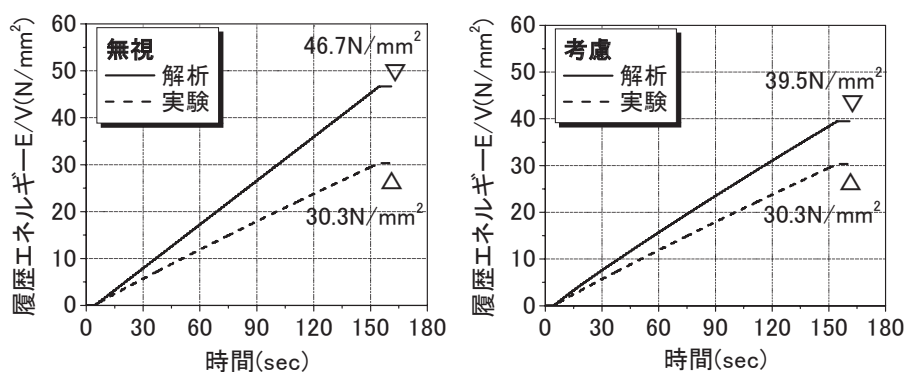

(a) 正弦波加振実験 HDB500g100t3.0c50

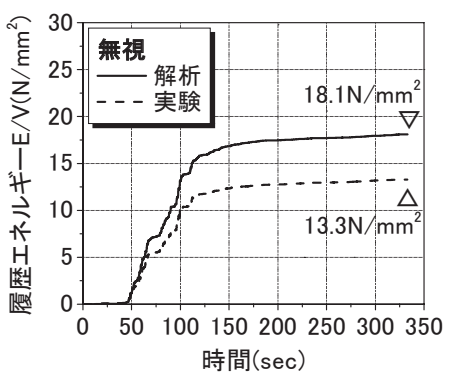

(b) 地震波加振実験 HDB500 三の丸波

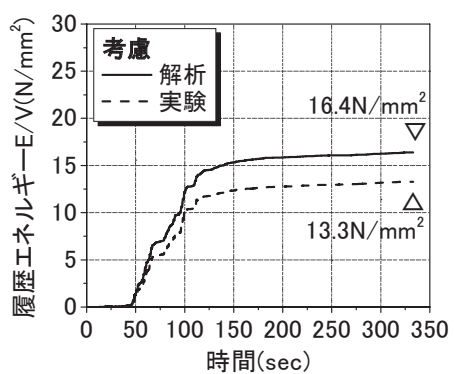

図 16 累積履歴エネルギー依存性を考慮した履歴エネルギーの検証

表 5 解析モデルの諸元

\begin{tabular}{|c|c|c|c|c|c|}
\hline $\begin{array}{c}\text { 直径 } \\
(\mathrm{mm})\end{array}$ & $\begin{array}{c}\text { ゴム総厚 } \\
(\mathrm{mm})\end{array}$ & $\begin{array}{c}\text { 面圧 } \\
\left(\mathrm{N} / \mathrm{mm}^{2}\right)\end{array}$ & $\begin{array}{c}T_{e q}(\gamma=1.0) \\
(\mathrm{s})\end{array}$ & $\begin{array}{c}T_{e q}(\gamma=2.0) \\
(\mathrm{s})\end{array}$ & $C_{d}(\gamma=2.0)$ \\
\hline 800 & 160 & 8 & 3.0 & 3.4 & 0.043 \\
\hline 800 & 160 & 11 & 3.5 & 4.0 & 0.031 \\
\hline 1000 & 200 & 13 & 4.1 & 4.7 & 0.026 \\
\hline $1200^{* 1)}$ & 250 & 13 & 4.6 & 5.2 & 0.026 \\
\hline
\end{tabular}

表 6 検討用入力地震動

\begin{tabular}{|c|c|c|c|c|c|c|}
\hline 地震 & 地点 & 地震波名 & $\begin{array}{c}\text { 最大加速度 } \\
\left(\mathrm{cm} / \mathrm{s}^{2}\right)\end{array}$ & $\begin{array}{c}\text { 最大速度 } \\
(\mathrm{cm} / \mathrm{s})\end{array}$ & $\begin{array}{l}\text { 計測 } \\
\text { 震度 }\end{array}$ & $\begin{array}{l}\text { 継続時 } \\
\text { 間 }{ }_{e} t_{0}(\mathrm{~s})\end{array}$ \\
\hline \multicolumn{2}{|c|}{ 模擬波 } & ART HACHI & 466.7 & 64.0 & 5.5 & 55.7 \\
\hline 直下型地震 & 神戸海洋気象台 & JMA KOBE NS & 818.0 & 91.7 & 6.4 & 9.54 \\
\hline \multirow{3}{*}{$\begin{array}{l}\text { 長周期地震動 } \\
\text { 予測波 }\end{array}$} & 名古屋三の丸 & C-SAN-EW & 185.9 & 50.5 & 5.2 & 119.9 \\
\hline & 大阪管区気象台 & KK-OSA-NS & 68.3 & 28.3 & 4.5 & 214.1 \\
\hline & 西大阪 & KK-WOS-EW & 69.3 & 24.8 & 4.6 & 179.4 \\
\hline
\end{tabular}

ギー依存性の考慮と無視の比較が主検討なため，1.0にした。

検討に用いる入力地震動は, 「標準波・告示波」に相当する模擬波 として，Bi-linear 形状の速度応答スペクトル $S_{V}=100 \mathrm{~cm} / \mathrm{s}(h=5 \%)$ を目 標スペクトルとし, 位相特性として HACHINOHE EW を用いた ART HACHI を作成する ${ }^{8)}$ 。直下地震として, 1995 年兵庫県南部地震の観 測波 JMA KOBE NS を，長周期地震動として，東海・東南海地震を 想定した名古屋三丸波 C-SAN-EW，南海地震を想定した大阪管区気 象台波 KK-OSA-NS と西大阪波 KK-WOS-EW を採用寸る ${ }^{1)}$ 。検討用 地震動を表 6 に示す。

\section{3 積層ゴムの熱・学的連成挙動が応答に与える影響}

免震構造においては，免震層で総入力エネルギーのほとんど大部 分を吸収してしまうため, エネルギーのつり合い式は上部構造を剛 体と見なし，次式のように表す9)。

$$
{ }_{D} W_{e}+{ }_{D} W_{p}=E
$$

ここで， ${ }_{D} W_{e}:$ 高減衰積層ゴムの弾性振動エネルギー

${ }_{D} W_{p}$ : 高減衰積層ゴムによる累積履歴エネルギ一吸収量

$$
E: \text { 入力エネルギー }\left(=M \cdot V_{E}^{2} / 2\right)
$$

図 17 に高減衰積層ゴムの復元力特性を弾性成分と減衰成分に分 けて示す。高減衰積層ゴムが蓄える弾性歪エネルギー ${ }_{D} W_{e}$ は図 17(a) に示寸三角形の面積で表される。高減衰積層ゴムが消費する減衰エ 
ネルギー ${ }_{D} W_{p}$ は, 図 $17(\mathrm{~b})$ に示す最大変位振幅時の履歴ループ面積 $\Delta_{D} W_{p}$ の等価繰返し数 $n_{1}$ 倍で表される。この ${ }_{D} W_{e}$ と ${ }_{D} W_{p}$ を, (30)式 に代入すると，エネルギーの釣り合い式は次のように書ける。

$$
\frac{1}{2}{ }_{f} Q_{\max } \cdot \delta_{\max }+4 n_{1} \cdot{ }_{s} Q_{y} \cdot \delta_{\max }=\frac{1}{2} M \cdot V_{E}^{2}
$$

ここに, ${ }_{s} Q_{Y}:$ 高減衰積層ゴムの切片荷重 $\left(=\alpha_{s} M g\right)$

$$
\begin{aligned}
& { }_{f} Q_{\max }: \text { 高減衰積層ゴムの弾性成分最大せん断力 }\left(=\alpha_{f} M g\right) \\
& \delta_{\max }: \text { 免震層の最大変位 } \\
& n_{1}: \text { 等価繰り返し数 } \\
& n_{1}=\frac{{ }_{D} W_{p}}{4_{s} Q_{y} \cdot \delta_{\max }}
\end{aligned}
$$

(31)式を解くと, 免震層の応答せん断力係数 $\alpha_{1}$ と最大変位 $\delta_{\max }$ の 関係が次式のように求まる ${ }^{8)}$ 。

$$
\left(\frac{\alpha_{1}}{\alpha_{0}}\right)=\frac{1}{8 n_{1}}\left\{\left(\frac{\delta_{0}}{\delta_{\max }}\right)+\left(8 n_{1}-1\right)\left(\frac{\delta_{\max }}{\delta_{0}}\right)\right\}
$$

ここに, $\alpha_{1}$ : 免震層の応答せん断力係数 $\left(=\alpha_{f}+\alpha_{s}\right)$

$$
\alpha_{0}=\frac{2 \pi \cdot V_{E}}{T_{f} \cdot g}, \quad \delta_{0}=\frac{T_{f} \cdot V_{E}}{2 \pi}
$$

ここに, $T_{f}=2 \pi \sqrt{M / k_{f}}$ : 免震周期

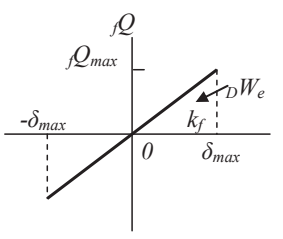

(a) 弾性成分（柔要素

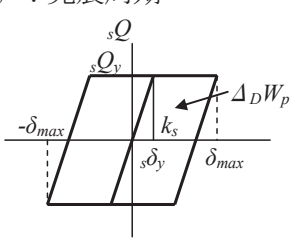

(b) 減衰成分 (剛要素)

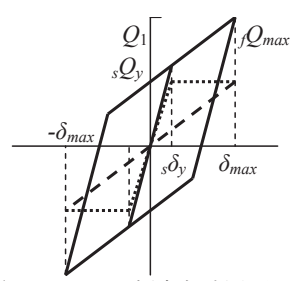

(c) 高減衰積層ゴム
図 17 高減衰積層ゴムの復元力特性

表 5 に示す 4 つの解析モデルの表 6 に示寸検討用入力地震動 5 波 による応答結果一覧を表 7 に示す。表中の $n_{1}$ は(32)式を用い, 累積 履歴エネルギ一依存性を考慮する場合の最大変位時の履歴ループは 地震終了時の累積履歷エネルギーを用いて求める。また, 地震波 5 波のエネルギースペクトルとそれらの地震動による4つの解析モデ ルの入力エネルギーの速度換算值 $V_{E}$ の関係を図 18 に示す。図中, 解析モデルの $V_{E}$ は積層ゴムのせん断ひずみ $\gamma=1.0$ 時の等価周期上 にプロットしており, 免震層変位が大きくなると等価周期が長くな ることを考慮すると両者は良く一致している。表 5 と図 18 より， ART HACHI と JMA KOBE NS は, 累積履歷エネルギー依存性考慮 と無視の差はほとんどなく, どの等価周期のモデルでも免震層変位 $\delta_{\max }$ は $0.3 \mathrm{~m}$ 以下であり, $V_{E}$ も $85 \sim 150 \mathrm{~cm} / \mathrm{s}, n_{1}$ も 1.8〜 5.6 にとどま る。長周期地震動は, 地震波により大きな值を示すモデルが異なり,

C-SAN-EW では， $\delta_{\max }$ は $0.4 \mathrm{~m}$ 近い值を示し， $V_{E}$ も $240 \sim 380 \mathrm{~cm} / \mathrm{s}$, $n_{1}$ も 11〜16 と大きな值を示す。KK-OSA-NS と KK-WOS-EW も, $T_{e q}=4.1,4.6 \mathrm{~s}$ のモデルで $\delta_{\max }=0.27 \sim 0.35 \mathrm{~m}, \quad V_{E}=240 \sim 380 \mathrm{~cm} / \mathrm{s}, \quad n_{1}=6$ 〜11 と大きな值を示す。このように大きな応答を示すモデルで累積 履歴エネルギー依存性考慮と無視の差が大きい。

等価周期 $T_{e q}=4.1 \mathrm{~s}(\gamma=1.0)$ の解析モデルの JMA KOBE NS と KK-WOS-EW による免震層の履歴曲線と累積履歴エネルギーの時 刻歴をそれぞれ図 19, 図 20 に示寸。また, KK-WOS-EW の免震層 変位の時刻歴波形を図 21 に示寸。図中の実線は累積履歴エネルギー 依存性を考慮した場合を，破線は無視した場合を示す。図 19，20

\begin{tabular}{|c|c|c|c|c|c|c|c|c|}
\hline \multirow[b]{2}{*}{ 地震波 } & \multicolumn{4}{|c|}{ 熱- 力学的連成挙動依存性考慮 } & \multicolumn{4}{|c|}{ 熱- 力学的連成挙動依存性無視 } \\
\hline & $\delta_{\operatorname{Imax}}(\mathrm{m})$ & $\alpha_{1}$ & $V_{E}(\mathrm{~cm} / \mathrm{s})$ & $n_{1}$ & $\delta_{\text {Imax }}(\mathrm{m})$ & $\alpha_{1}$ & $V_{E}(\mathrm{~cm} / \mathrm{s})$ & $n_{1}$ \\
\hline ART HACHI & 0.298 & 0.057 & 141 & 4.8 & 0.294 & 0.059 & 140 & 4.3 \\
\hline JMA KOBE NS & 0.260 & 0.056 & 91 & 2.1 & 0.260 & 0.054 & 140 & 4.9 \\
\hline C-SAN-EW & 0.391 & 0.064 & 251 & 12.7 & 0.381 & 0.070 & 270 & 12.5 \\
\hline KK-OSA-NS & 0.268 & 0.054 & 162 & 7.2 & 0.267 & 0.055 & 158 & 6.1 \\
\hline KK-WOS-EW & 0.350 & 0.056 & 231 & 11.9 & 0.287 & 0.058 & 208 & 9.9 \\
\hline
\end{tabular}

表 7 応答結果一覧表

(a) $T_{e q}=3.0 \mathrm{~s}(\gamma=1.0)$

\begin{tabular}{|l|c|c|c|c|c|c|c|c|}
\hline \multirow{2}{*}{\multicolumn{1}{|c|}{ 地震波 }} & \multicolumn{3}{|c|}{ 熱・学的連成挙動依存性考慮 } & \multicolumn{3}{|c|}{ 熱・学的連成挙動依存性無視 } \\
\cline { 2 - 10 } & $\delta_{\text {Imax }}(\mathrm{m})$ & $\alpha_{1}$ & $V_{E}(\mathrm{~cm} / \mathrm{s})$ & $n_{1}$ & $\delta_{\text {Imax }}(\mathrm{m})$ & $\alpha_{1}$ & $V_{E}(\mathrm{~cm} / \mathrm{s})$ & $n_{1}$ \\
\hline ART HACHI & $\mathbf{0 . 1 7 1}$ & $\mathbf{0 . 0 7 5}$ & $\mathbf{1 4 8}$ & $\mathbf{5 . 6}$ & $\mathbf{0 . 1 8 0}$ & $\mathbf{0 . 0 8 0}$ & $\mathbf{1 4 7}$ & $\mathbf{4 . 8}$ \\
\hline JMA KOBE NS & $\mathbf{0 . 2 7 2}$ & $\mathbf{0 . 1 0 0}$ & $\mathbf{1 1 8}$ & $\mathbf{2 . 2}$ & $\mathbf{0 . 2 6 9}$ & $\mathbf{0 . 1 0 1}$ & $\mathbf{1 1 7}$ & $\mathbf{2 . 1}$ \\
\hline C-SAN-EW & $\mathbf{0 . 3 8 0}$ & $\mathbf{0 . 1 0 9}$ & $\mathbf{3 5 3}$ & $\mathbf{1 6 . 5}$ & $\mathbf{0 . 3 9 5}$ & $\mathbf{0 . 1 3 6}$ & $\mathbf{3 8 1}$ & $\mathbf{1 4 . 9}$ \\
\hline KK-OSA-NS & $\mathbf{0 . 1 3 9}$ & $\mathbf{0 . 0 7 2}$ & $\mathbf{1 4 9}$ & $\mathbf{7 . 0}$ & $\mathbf{0 . 1 4 0}$ & $\mathbf{0 . 0 7 2}$ & $\mathbf{1 4 8}$ & $\mathbf{6 . 3}$ \\
\hline KK-WOS-EW & $\mathbf{0 . 1 1 4}$ & $\mathbf{0 . 0 6 6}$ & $\mathbf{1 5 2}$ & $\mathbf{9 . 0}$ & $\mathbf{0 . 1 1 0}$ & $\mathbf{0 . 0 6 6}$ & $\mathbf{1 5 0}$ & $\mathbf{8 3}$ \\
\hline
\end{tabular}

(b) $T_{e c}=3.5 \mathrm{~s}(\gamma=1.0)$

\begin{tabular}{|l|c|c|c|c|c|c|c|c|}
\hline \multirow{2}{*}{\multicolumn{1}{|c|}{ 地震波 }} & \multicolumn{3}{|c|}{ 熱・学的連成挙動依存性考慮 } & \multicolumn{3}{c|}{ 熱・学的連成挙動依存性無視 } \\
\cline { 2 - 10 } & $\delta_{\text {Imar }}(\mathrm{m})$ & $\alpha_{1}$ & $V_{E}(\mathrm{~cm} / \mathrm{s})$ & $n_{1}$ & $\delta_{\text {Imar }}(\mathrm{m})$ & $\alpha_{1}$ & $V_{E}(\mathrm{~cm} / \mathrm{s})$ & $n_{1}$ \\
\hline ART HACHI & $\mathbf{0 . 1 7 1}$ & $\mathbf{0 . 0 7 5}$ & $\mathbf{1 4 7 . 6}$ & $\mathbf{5 . 6}$ & $\mathbf{0 . 1 8 0}$ & $\mathbf{0 . 0 8 0}$ & $\mathbf{1 4 6 . 9}$ & $\mathbf{4 . 8}$ \\
\hline JMA KOBE NS & $\mathbf{0 . 2 7 2}$ & $\mathbf{0 . 1 0 0}$ & $\mathbf{1 1 8 . 2}$ & $\mathbf{2 . 2}$ & $\mathbf{0 . 2 6 9}$ & $\mathbf{0 . 1 0 1}$ & $\mathbf{1 1 7 . 2}$ & $\mathbf{2 . 1}$ \\
\hline C-SAN-EW & $\mathbf{0 . 3 8 0}$ & $\mathbf{0 . 1 0 9}$ & $\mathbf{3 5 2 . 5}$ & $\mathbf{1 6 . 5}$ & $\mathbf{0 . 3 9 5}$ & $\mathbf{0 . 1 3 6}$ & $\mathbf{3 8 1 . 4}$ & $\mathbf{1 4 . 9}$ \\
\hline KK-OSA-NS & $\mathbf{0 . 1 3 9}$ & $\mathbf{0 . 0 7 2}$ & $\mathbf{1 4 8 . 7}$ & $\mathbf{7 . 0}$ & $\mathbf{0 . 1 4 0}$ & $\mathbf{0 . 0 7 2}$ & $\mathbf{1 4 7 . 9}$ & $\mathbf{6 . 3}$ \\
\hline KK-WOS-EW & $\mathbf{0 . 1 1 4}$ & $\mathbf{0 . 0 6 6}$ & $\mathbf{1 5 2 . 4}$ & $\mathbf{9 . 0}$ & $\mathbf{0 . 1 1 0}$ & $\mathbf{0 . 0 6 6}$ & $\mathbf{1 5 0 . 5}$ & $\mathbf{8 . 3}$ \\
\hline
\end{tabular}

$T_{e q}=4.1 \mathrm{~s}(\gamma=1.0)$

(d) $T_{e q}=4.6 \mathrm{~s}(\gamma=1.0)$

\begin{tabular}{|l|c|c|c|c|c|c|c|c|}
\hline \multirow{2}{*}{\multicolumn{1}{|c|}{ 地震波 }} & \multicolumn{3}{|c|}{ 熱・学的連成挙動依存性考慮 } & \multicolumn{4}{c|}{ 熱・学的連成挙動依存性無視 } \\
\cline { 2 - 10 } & $\delta_{\text {Imax }}(\mathrm{m})$ & $\alpha_{1}$ & $V_{E}(\mathrm{~cm} / \mathrm{s})$ & $n_{1}$ & $\delta_{\text {Imax }}(\mathrm{m})$ & $\alpha_{1}$ & $V_{E}(\mathrm{~cm} / \mathrm{s})$ & $n_{1}$ \\
\hline ART HACHI & $\mathbf{0 . 2 9 8}$ & $\mathbf{0 . 0 5 1}$ & $\mathbf{1 4 1}$ & 4.7 & $\mathbf{0 . 3 0 0}$ & $\mathbf{0 . 0 5 2}$ & $\mathbf{1 3 9}$ & $\mathbf{4 . 2}$ \\
\hline JMA KOBE NS & $\mathbf{0 . 2 5 8}$ & $\mathbf{0 . 0 5 1}$ & $\mathbf{8 7}$ & $\mathbf{1 . 9}$ & $\mathbf{0 . 2 5 6}$ & $\mathbf{0 . 0 4 8}$ & $\mathbf{8 5}$ & $\mathbf{1 . 8}$ \\
\hline C-SAN-EW & $\mathbf{0 . 4 0 0}$ & $\mathbf{0 . 0 5 7}$ & 239 & $\mathbf{1 1 . 0}$ & $\mathbf{0 . 3 9 5}$ & $\mathbf{0 . 0 6 2}$ & $\mathbf{2 5 3}$ & $\mathbf{1 0 . 6}$ \\
\hline KK-OSA-NS & $\mathbf{0 . 2 8 4}$ & $\mathbf{0 . 0 5 0}$ & $\mathbf{1 7 0}$ & $\mathbf{7 . 5}$ & $\mathbf{0 . 2 8 2}$ & $\mathbf{0 . 0 5 1}$ & $\mathbf{1 6 6}$ & $\mathbf{6 . 4}$ \\
\hline KK-WOS-EW & $\mathbf{0 . 3 5 3}$ & $\mathbf{0 . 0 5 3}$ & $\mathbf{2 4 4}$ & $\mathbf{1 3 . 1}$ & $\mathbf{0 . 3 2 2}$ & $\mathbf{0 . 0 5 4}$ & $\mathbf{2 2 9}$ & $\mathbf{1 0 . 6}$ \\
\hline
\end{tabular}

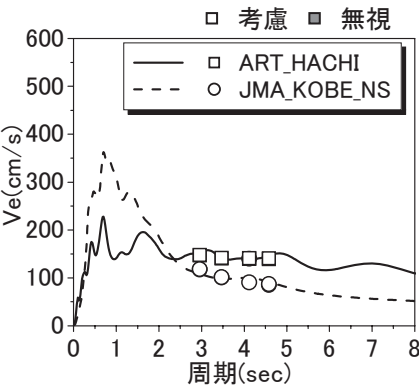

(a) 告示波・直下地震
$\Delta$ 考慮 $\Delta$ 無視

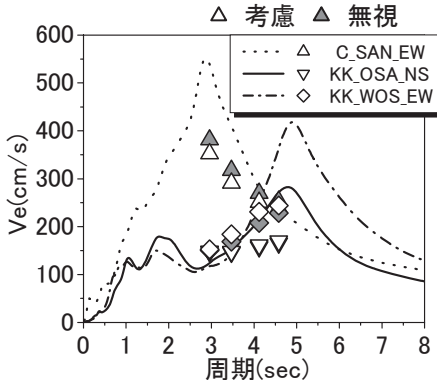

(b) 長周期地震動
図 18 エネルギースペクトルと入力の換算速度值

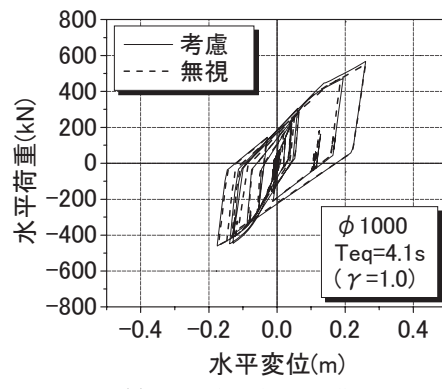

(a) JMA KOBE NS

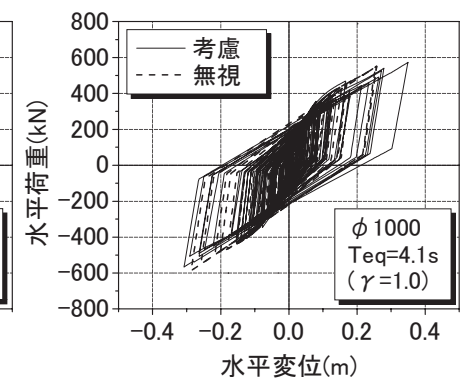

(b) KK-WOS-EW
図 19 熱・力学的連成挙動の影響の免震層の履歴曲線による比較

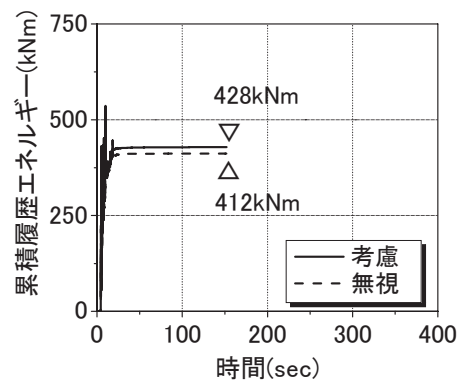

(a) JMA KOBE NS

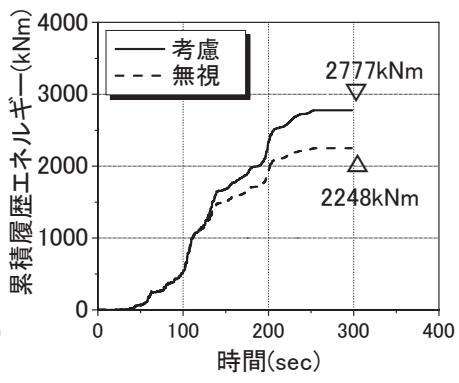

(b) KK-WOS-EW
図 20 熱・力学的連成挙動の影響の累積履歴エネルギー時刻歷による比較 
より, JMA KOBE NS では, 履歴曲線, 累積履歴エネルギーともに 累積履歴エネルギー依存性の考慮と無視の差はほとんど無く,

KK-WOS-EW では, 考慮することにより入力エネルギーも増加する が，それ以上に剛性低下と変形の増加が見られる。図 21 より, 無視 モデルでは 100 秒過ぎに $0.29 \mathrm{~m}$ の最大変形を生じたものが，考慮モ デルでは累積履歴エネルギーの増加に伴い減衰性能が低下し，100s 過ぎの最大変形を上回る $0.35 \mathrm{~m}$ の変形が $200 \mathrm{~s}$ 過ぎに現れる。

地震波 5 波のエネルギースペクトルとそれらの地震動による 4 つ
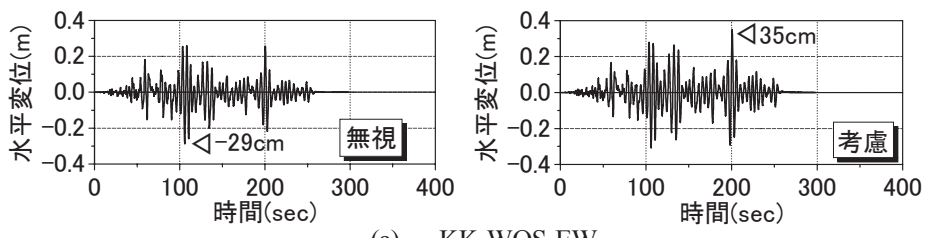

(a) KK-WOS-EW

図 21 熱・力学的連成挙動の影響の免震層変位時刻歴波形による比較

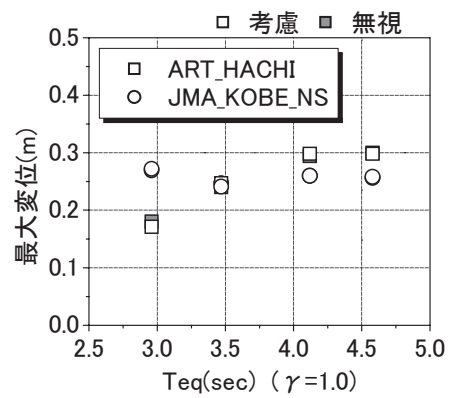

(a) 告示波・直下地震

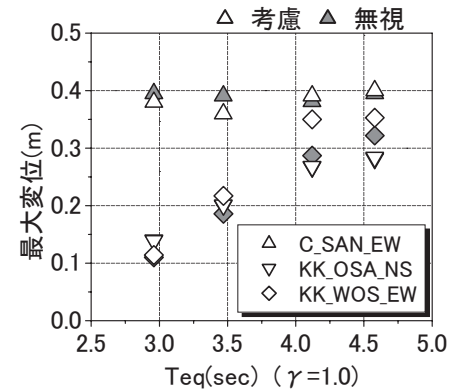

(b) 長周期地震動
図 22 熱・力学的連成挙動の影響の免震層変位による比較

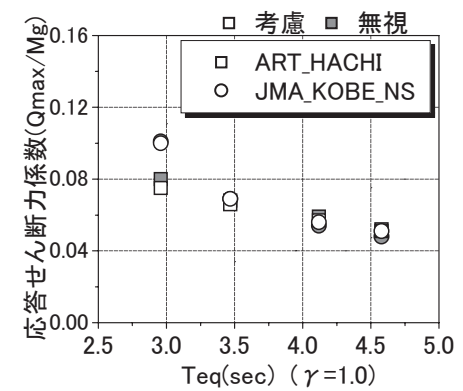

(a)告示波・直下地震

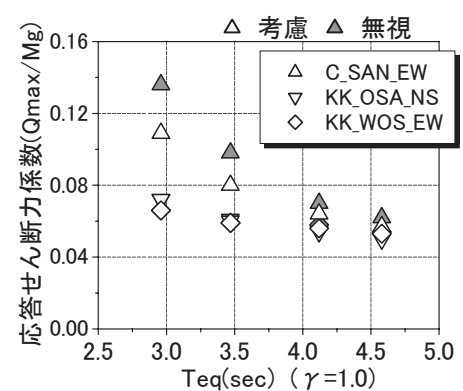

(b)長周期地震動
図 23 熱・学的連成挙動の影響の応答せん断力係数による比較

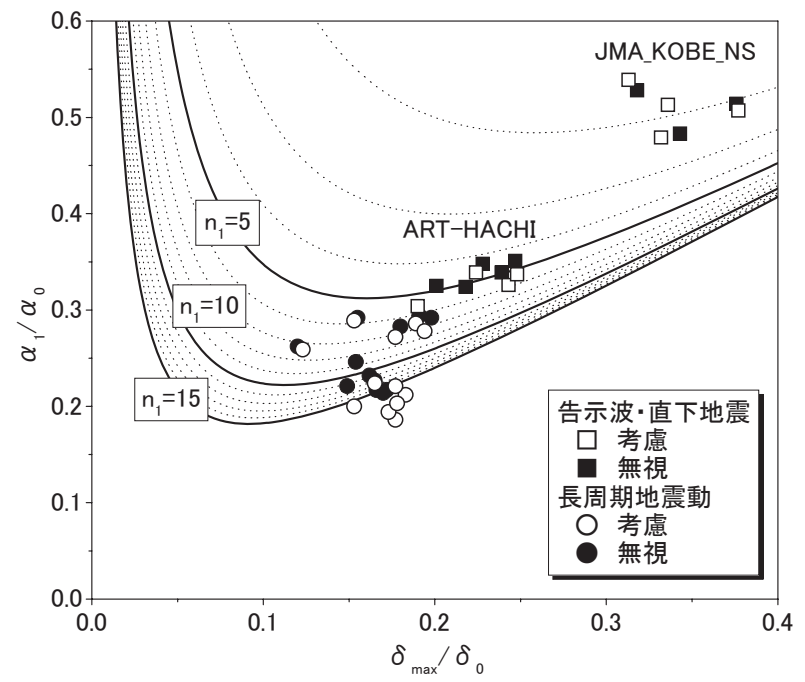

図 24 熱・力学的連成挙動の影響の等価繰返し数による比較
の解析モデルの免震層の最大変位と最大層せん断力係数を図 22,23

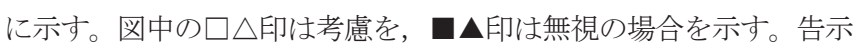
波・直下地震である ART HACHI と JMA KOBE NS は，考慮・無視 の差がほとんど見られない。一方, 長周期地震動である C-SAN-EW , KK-OSA-NS と KK-WOS-EW では，考慮と無視で差が現れている。 また，表 7 と図 18 からわかるように，考慮と無視により $V_{E}$ が異な るため累積履歷エネルギ一依存性の影響を評価するには，これらの 図では十分でない。そこで， $T_{f}$ と $V_{E}$ を取り込んだ(34)式の $\alpha_{0}$ と $\delta_{0}$ を用いて免震層変位 $\delta_{\text {max }}$ とせん断力係数 $\alpha_{1}$ を無次元化して, 免震 層の最大変位と最大層せん断力係数を図 24 に示寸。図中の点線と実 線は $n_{1}=2.0 \sim 15.0$ の時の(33)式を表す。ART HACHI と JMA KOBE NS は，考慮と無視による明確な傾向が見られないが，長周期地震動で は，概ね免震層変位が大きくなり，せん断力係数が若干小さくなる 傾向を示す。

\section{8. 結論}

本論文では，高減衰積層ゴムの大振幅・多数回繰返し変形下での 動的載荷実験に基づき，積層ゴム内部での温度分布はほぼ一様で内 部温度と累積履歴エネルギー吸収量は相関関係にあることを見出し， 単位体積当たりの累積履歴エネルギー吸収量と水平剛性や減衰性能 との関係を表す実験式を導出した。この累積履歴エネルギー依存式 を既往の復元力特性に組込んだ 1 質点系免震建物モデルを作成し， 告示波・直下地震波と長周期地震動による地震応答解析を行った。

1 種類の高減衰積層ゴムの縮尺率 1/4.4 1/2 の $\phi 225, \phi 300, \phi$ 500 の縮小試験体を用いた限られた動的載荷実験に基づくものであ るが，高減衰積層ゴムが地震入力エネルギーを消費することで内部 温度が上昇し，それに伴い水平剛性と減衰性能が低下寸る熱・力学 的連成挙動が，長周期地震動を入力とする免震建物の応答挙動に与 える影響を評価する方法を示せたと考える。

\section{謝辞}

本研究は, 平成 18,19 年度文部科学省科学研究費補助金(基盤研究(B)課題番 号:18360271，研究代表者:竹中康雄)の援助の下，鹿島建設㑣，(㑊ブリヂストン，東 京理科大学北村研究室の共同研究の一部です。共同研究者の鹿島建設㑣の近藤明洋 氏, 引田真規子氏, 本間友規氏, 侏ブリヂストンの菊地隆志氏から協力を得ました。 また, 四表の作成には東京理科大学北村研究室の大学院生下沖航君の協力を得まし た。地震波は, 日本建築学会・東海地震等巨大災害一の対応特別調査委員会と国土 交通省中部地方整備局の中田猛氏から提供を受けました。ここに感謝の意を示しま す。

\section{参考文献}

1) 日本建築学会東海地震等巨大災害への対応特別調査委員会 : 長周期地震動と建 築物の耐震性, 日本建築学会, 2007.12

2) 日本免震構造協会編 : 免震部材標準品リス卜 2009 版, 2009.11

3) 鳥井,室田他:高減衰積層ゴムの各種依存性を評価した解析手法と製品検査に関 する一考察,日本建築学会技術報告集,第 8 号,pp101-106,1999-6

4) ブリヂストン，高減衰積層ゴム（X0.6）技術資料,認定番号:MVBR-0341，2007.4

5) 日本建築センター編 : 免震建築物の技術基準解説及び計算例とその解説, 2001.5

6) 北村春幸, 東野さやか, 竹中康雄, 田村和夫 : 長周期地震動による既存免震建 物の而震性能評価, 日本建築学会技術報告集, 第 22 号, pp.127-132, 2005.12

7) 竹中康雄, 近藤明洋, 高岡栄治, 引田真規子, 北村春幸，仲村崇仁 : 積層ゴム の熱・学的連成挙動に関する実験的研究, 日本建築学会構造系論文集, 第 74 巻, 第 646 号, pp.2245-2253, 2009.12

8) 北村春幸 : 性能設計のため建築振動解析入門(第 2 版)，彰国社，2009.4

9) 秋山宏 : エネルギーの釣り合いに基づく建築物の耐震設計，技報堂出版，1999.1 